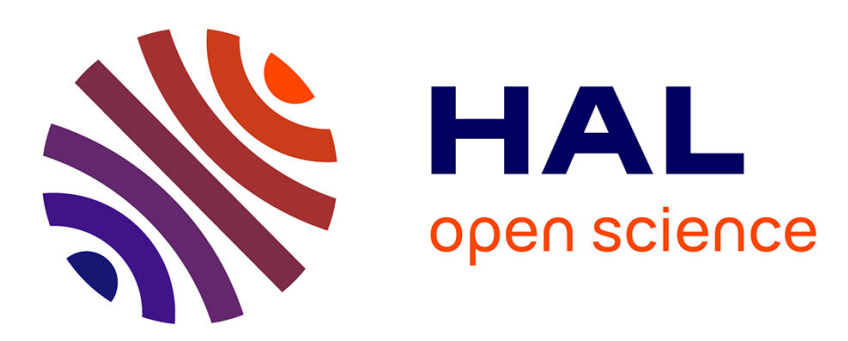

\title{
Nature or nurture: Let food be your epigenetic medicine in chronic inflammatory disorders
}

Katarzyna Szarc Vel Szic, 'Matladi Ndlovu N, Guy Haegeman, Wim Vanden

Berghe

\section{- To cite this version:}

Katarzyna Szarc Vel Szic, 'Matladi Ndlovu N, Guy Haegeman, Wim Vanden Berghe. Nature or nurture: Let food be your epigenetic medicine in chronic inflammatory disorders. Biochemical Pharmacology, 2010, 80 (12), pp.1816. 10.1016/j.bcp.2010.07.029 . hal-00637154

\section{HAL Id: hal-00637154 \\ https://hal.science/hal-00637154}

Submitted on 31 Oct 2011

HAL is a multi-disciplinary open access archive for the deposit and dissemination of scientific research documents, whether they are published or not. The documents may come from teaching and research institutions in France or abroad, or from public or private research centers.
L'archive ouverte pluridisciplinaire $\mathbf{H A L}$, est destinée au dépôt et à la diffusion de documents scientifiques de niveau recherche, publiés ou non, émanant des établissements d'enseignement et de recherche français ou étrangers, des laboratoires publics ou privés. 


\section{Accepted Manuscript}

Title: Nature or nurture: Let food be your epigenetic medicine in chronic inflammatory disorders

Authors: Katarzyna Szarc vel Szic, 'Matladi Ndlovu N, Guy Haegeman, Wim Vanden Berghe

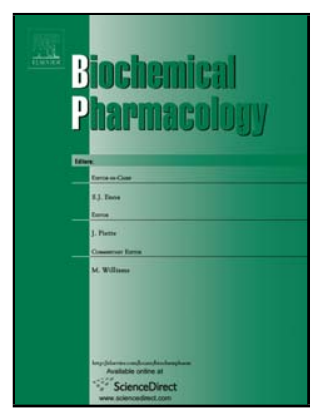

PII:

S0006-2952(10)00567-8

DOI:

doi:10.1016/j.bcp.2010.07.029

Reference:

BCP 10662

To appear in: $\quad B C P$

Received date: $\quad 26-5-2010$

Revised date: $\quad 19-7-2010$

Accepted date: $\quad$ 23-7-2010

Please cite this article as: Szic KS, N MN, Haegeman G, Berghe WV, Nature or nurture: Let food be your epigenetic medicine in chronic inflammatory disorders, Biochemical Pharmacology (2010), doi:10.1016/j.bcp.2010.07.029

This is a PDF file of an unedited manuscript that has been accepted for publication. As a service to our customers we are providing this early version of the manuscript. The manuscript will undergo copyediting, typesetting, and review of the resulting proof before it is published in its final form. Please note that during the production process errors may be discovered which could affect the content, and all legal disclaimers that apply to the journal pertain. 


\section{Metabolic Stress \\ Oxidative Stress}

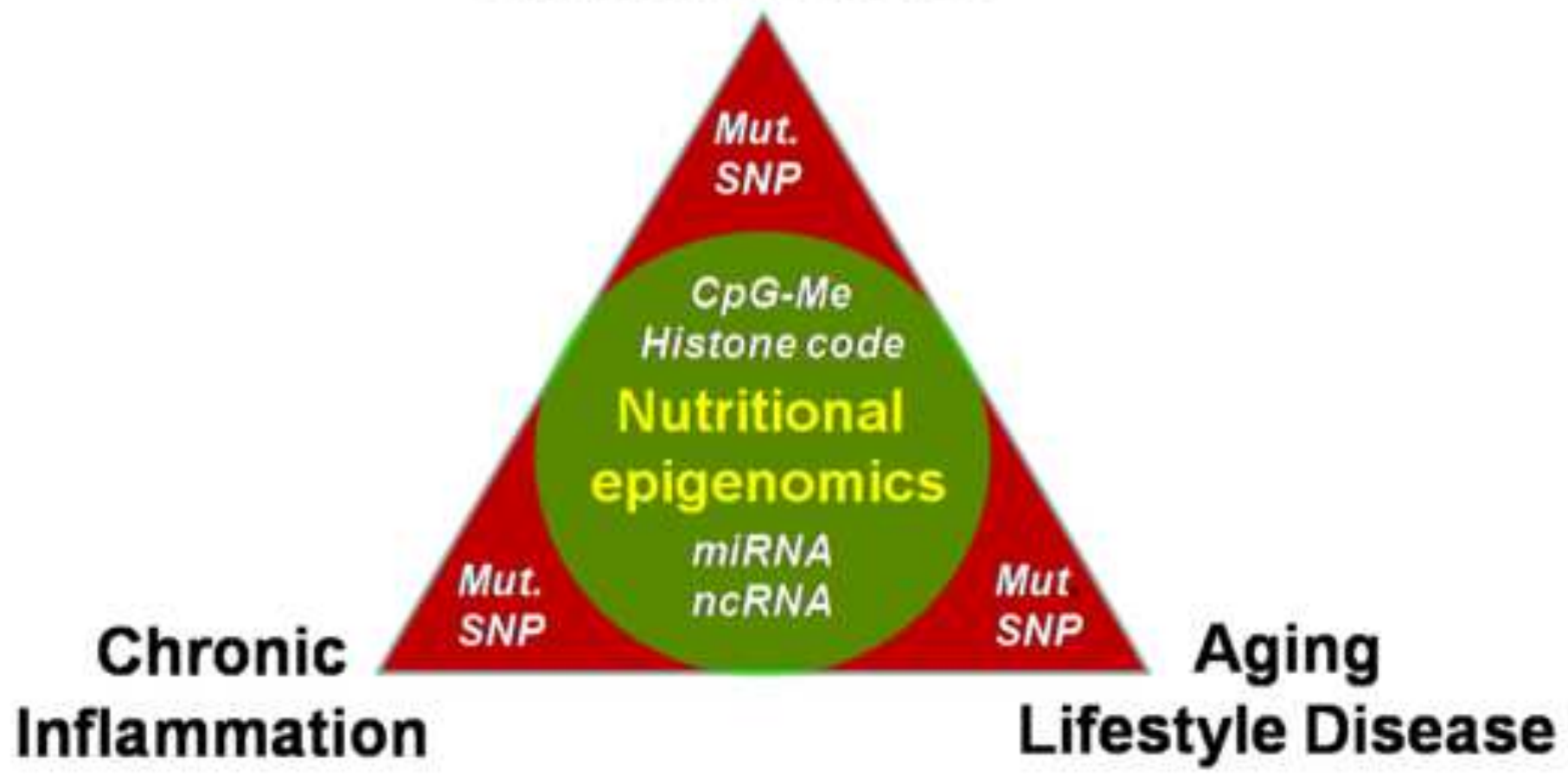




\section{Nature or nurture: Let food be your epigenetic medicine in chronic inflammatory} disorders

Katarzyna Szarc vel Szic ${ }^{1,2}$, 'Matladi Ndlovu N. ${ }^{1,3}$, Guy Haegeman ${ }^{1}$, Wim Vanden Berghe ${ }^{1,2}$

${ }^{1}$ Laboratory of Eukaryotic Gene Expression and Signal Transduction (LEGEST), Department of Physiology, Ghent University, K.L.Ledeganckstraat 35, Gent, Belgium

${ }^{2}$ Present address: Lab Protein Science, Proteomics and Epigenetic Signaling, Department of Biomedical Sciences, University Antwerp, Campus Drie Eiken, Universiteitsplein 1, Wilrijk, Belgium

${ }^{3}$ Present address: Laboratory of Cancer Epigenetics, Free University of Brussels, Faculty of Medicine, 808 route de Lennik, 1070 Brussels, Belgium

Corresponding author: wim.vandenberghe@ua.ac.be 


\begin{abstract}
:
Numerous clinical, physiopathological and epidemiological studies have underlined the detrimental or beneficial role of nutritional factors in complex inflammation related disorders such as allergy, asthma, obesity, type 2 diabetes, cardiovascular disease, rheumatoid arthritis and cancer. Today, nutritional research has shifted from alleviating nutrient deficiencies to chronic disease prevention. It is known that lifestyle, environmental conditions and nutritional compounds influence gene expression. Gene expression states are set by transcriptional activators and repressors and are often locked in by cell-heritable chromatin states. Only recently, it has been observed that the environmental conditions and daily diet can affect transgenerational gene expression via "reversible" heritable epigenetic mechanisms. Epigenetic changes in DNA methylation patterns at $\mathrm{CpG}$ sites (epimutations) or corrupt chromatin states of key inflammatory genes and noncoding RNAs, recently emerged as major governing factors in cancer, chronic inflammatory and metabolic disorders. Reciprocally, inflammation, metabolic stress and diet composition can also change activities of the epigenetic machinery and indirectly or directly change chromatin marks. This has recently launched re-exploration of anti-inflammatory bioactive food components for characterization of their effects on epigenome modifying enzymatic activities (acetylation, methylation, phosphorylation, ribosylation, oxidation, ubiquitination, sumoylation). This may allow to improve healthy aging by reversing disease prone epimutations involved in chronic inflammatory and metabolic disorders.
\end{abstract}




\section{Introduction}

A large body of epidemiological and experimental data has demonstrated a direct link between chronic inflammation and complex diseases such as obesity, allergy, asthma, cardiovascular disease, type 2 diabetes, rheumatoid arthritis, bowel disease and several types of cancer. Nutrition, as the main aspect of the environment, is said to play a key role in some of this disparities, however, the molecular mechanisms involved still remain to be unraveled [1-3]. Genome-wide association studies have identified hundreds of genetic variants associated with complex human diseases and traits, and have provided valuable insights into their genetic architecture. However, most variants identified so far confer relatively small increments in risk, leaving many questions how the remaining 'missing' heritability can be explained, although polygenic disease traits may account for some of this limitations [4, 5]. Furthermore, genetics per se cannot explain the vast diversity of phenotypes. A substantial number of studies have shown that contstraint in the early life environment is associated with increased risk of cardiometabolic disease, affective disorders and cognitive decline, osteoporosis, allergy, inflammation and specific cancers. Furthermore, genetics per se cannot explain the vast diversity of phenotypes. The differences between identical twins and their different susceptibility to most diseases has recently been attributed to epigenetic changes which accumulate during life following exposure to different environmental conditions [6-8]. The contribution of epigenetic changes (epimutations) to human disease is probably underestimated. Epigenetics encompasses several extra-genetic processes such as DNA methylation (methylation of cytosines within $\mathrm{CpG}$ dinucleotides), histone tail modifications (including acetylation, phosphorylation, methylation, sumoylation, ribosylation and ubiquitination), noncoding RNA functions, regulation of polycomb group proteins and the epigenetic cofactor modifiers, all of which may alter gene expression but do not involve changes in the DNA sequence itself [9-13]. The combinatorial nature of DNA methylation and histone modifications significantly extends the information potential of the genetic code. In a large scale comparative study, authors concluded a lack of genetic factor in chronic obstructive pulmonary disorder (COPD), cardiovascular disease (CVD), rheumatoid arthritis and Crohn's disease, all typical examples of diseases with an important inflammatory component [14]. A recent survey of the global incidence of cancer shows that the age-adjusted cancer incidence in the Western world is above 300 cases per 100,000 population, whereas that in Asian countries is less than 100 cases per 100,000. Sedentary lifestyle, diet, obesity and metabolic syndrome have been named as the major contributors to this phenomena, which is further emphasized by the increase in cancer cases among immigrants from Asian to 
Western countries $[15,16]$. As such, a reasonable good fraction of cancer deaths maybe prevented by modifying the diet composition (i.e. content of fiber, fruit, vegetable, fat/oil, protein, spices, cereals, xenobiotics) and regular physical exercise [3, 17]. Abnormalities in DNA methylation, histone modifications, chromatin remodelling and microRNA (miR) patterns $[12,18,19]$ are important hallmarks of inflammatory disease states and cancer [10, $12,13,20-22]$.

The most studied epigenetic lesion, which is DNA hypermethylation at the promoter region of many genes [20, 23], is proved to be responsible for silencing of more than 600 cancerrelated genes and this number is still rising. They include tumour suppressor genes, as well as genes involved in the cell-cycle regulation, DNA repair, angiogenesis, metastasis and apoptosis [24]. On the other hand, global hypomethylation of the DNA is said to activate endoparasitic sequences and causes the global chromosome instability leading to various mutations and cancer progression [21]. Now, it is becoming clear that epigenetic changes complement genetic mutations and importantly drive the development and progression of various diseases ranging from allergy, asthma, rheumatoid arthritis, type 2 diabetes, obesity, bowel disease, cardiovascular disease and cancer [12, 13, 20, 21, 25-29]. Recent successes of therapeutic intervention in chronic inflammatory diseases using epigenetic modifiers such as histone deacetylase (HDAC) and DNA methyltransferase (DNMT) inhibitors has fuelled interest in exploring epigenomic maps of inflammatory disease states [30, 31]. Interestingly, emerging data demonstrate the direct influence of certain anti-inflammatory dietary factors (for example polyphenols, isothiocyanates, epicatechins) and micronutrients (for example folic acid, selenium) on heritable gene expression and DNA methylation or chromatin remodelling [32-40]. Because epigenetic changes are reversible, developing drugs that control epigenetic regulation now attract substantial research investment, including the development of functional foods or supplements as nutrition based epigenetic modulators which will be discussed in more detail below [2, 30, 41]

\section{Extragenomic epigenetic information}

The definition of 'epigenetics' evolved during the past 50 years into the current and common definition of 'heritable changes in gene function that cannot be explained by changes in DNA sequence, although some definitions have excluded heritability [42]. While "inheritance" and "heritability" strictly spoken, refer to intergenerational organismal phenomena, they are also widely used today for describing both molecular and phenotypic characteristics at the cellular level that are transmitted between mitotic cell division. Expression of our DNA genotype can 
be twiddled by various volume knobs. Considerable cross-talk occurs between three main players in silencing: DNA methylation, histone modifications and noncoding RNAs. The chromatin template therefore serves as the major platform for epigenetic regulation in the form of DNA methylation, histone modifications and histone variants. More recently, an epigenetic role for RNA has also been demonstrated in normal situations as well as in disease [12]. Before most activators of a gene access their DNA-binding sites, a transition from a condensed ("solenoid-like fiber") to a decondensed ("beads on a string") chromatin structure appears to take place. Conversely, the acquisition of a more condensed chromatin structure is often associated with gene silencing [11]. This structural restriction of chromatin on gene expression can be overcome by chromatin remodeling cofactor complexes, which reversibly modify (acetylation, phosphorylation, ubiquitylation, glycosylation, sumoylation) on lysine, arginistine, serine or threonine residues of amino-terminal histone tails. In general, DNA is wrapped around nucleosomes, which are arranged as regularly spaced beads (146 bp DNA/nucleosome) along the DNA. Typically, nucleosomes consist of a histone octamer of histones $(\mathrm{H}) 2 \mathrm{~A} / \mathrm{B}, \mathrm{H} 3$ and $\mathrm{H} 4$. The DNA bridging two adjacent nucleosomes is normally bound by the linker histone H1 and is termed linker DNA. While the core histones are bound relatively tightly to DNA, chromatin is largely maintained by the dynamic association with its architectural proteins. Since the discovery of histone modifying enzymes, N-terminal histone tails protruding from nucleosomes were found to be 'velcro patches' for (de)acetylases (HDAC/HAT), (de)methylases (HMT/HDMT), ubiquitin ligases, small ubiquitin-related modifier (SUMO) ligases, kinases, phosphatases, ribosylases, which together establish specific histone modification patterns involved in transcription [11]. Specific sets of histone modifications and/or variants are associated with genes that are actively transcribed or are repressed, a phenomenon defined as the "histone code" [11]. Since the modifications do not involve underlying changes in nucleotide or amino acid sequences, they are "above the genome" and as such termed "epigenomic". However, to establish specificity of epigenetic marks, histone modifying complexes have to be recruited to relevant genomic locations by DNA-binding proteins, RNAs or protein-RNA complexes that bind to their specific DNA sites as a consequence of their own binding specificities and cellular concentrations [43-46]. It cannot come from the enzymatic activities per se as neither DNMTs, nor enzymes which modify histones know which part of the genome needs to be tagged. Furthermore, there is now a large body of evidence showing that modifications of the histone tails provide signals ("binary switches") that are recognized by specific binding proteins, such as chromo-, bromoor tudor-domains which in turn can influence gene expresion and other chromatin functions 
[47-49]. The spatial and time-dependent combinations of histone modifications further increase the complexity of information contained in chromatin [11, 48, 49].

DNA methylation is the best-known epigenetic mark [20,50]. It is catalyzed by two types of DNMTs: DNMT1 is a maintenance methyltransferase, whereas both DNMT3A and DNMT3B are de novo methyltransferases [51, 52]. The role of DNMT2 in DNA methylation is minor, its enzymology being largely directed to tRNA. DNA methylation is normally associated with gene inactivation and it usually occurs in $\mathrm{CpG}$ dinucleotides. Alternatively, DNA methylation of transcription factor binding sites which prevents binding of repressor proteins, may paradoxically induce gene activation. CpGs are normally methylated when scattered throughout the genome, but are mostly unmethylated when they are clustered as $\mathrm{CpG}$ islands at 5' ends of many genes. Hypermethylation of CpG-rich promoters triggers local histone code modifications resulting in a cellular camouflage mechanism that sequesters gene promoters away from transcription factors and results in stable silencing of gene expression. DNA methylation at $\mathrm{CpG}$ dinucleotides occurs upon transfer of $\mathrm{S}$ adenosylmethionine (SAM) on cytosine by DNMTs. Whereas DNMT3A/B are responsible for DNA methylation during development (differentiation), DNMT1 is in charge of maintaining DNA methylation patterns in DNA replication during cell division. In mammalian cells, the fidelity of maintenance of methylation is $97-99.9 \%$ per mitosis, whereas de novo methylation is as high as $3-5 \%$ per mitosis, thus creating possibilities for epigenetic changes. DNA methylation also regulates genomic imprinting [53], Xchromosome inactivation [54] and silencing of repetitive sequences [55]. Although in most cases DNA methylation is a stable epigenetic mark, reduced levels of methylation can also be observed during development. This net loss of methylation can either occur passively by replication in the absence of cuntional maintenance methylation pathways, or actively, by removing methylated cytosines. In plants active demethylation is achieved in plants by DNA glycosylase activity, probably in combination with the base excision repair pathway. In mammals, coupling of 5-methylcytosine deaminase and thymine DNA glycosylase activities maybe responsible for DNA demethylation. Alternatively, a role for the 5hydroxymethylcytosine modification in mammalian DNA demethylation has also been proposed as an intermediate in an active DNA demethylation pathway involving DNA repair and 5-hydroxymethylcytosine-specific DNA glycosylase activity [52].

Although DNA methylation is the best-known epigenetic mark [51, 56, 57], DNA methylation does not act alone. It occurs in the context of nucleosome positioning and histone modifications [9, 58, 59]. For example, high resolution DNA methylation analysis has 
revealed 10-base periodicities (i.e one helical turn) in the DNA methylation status of nucleosome-bound DNA and found that nucleosomal DNA was more highly methylated than flanking DNA [59]. These data revealed that nucleosome positioning influences DNA methylation patterning of promoters and intron-exon boundaries throughout the genome and that DNA methyltransferases preferentially target nucleosome-bound DNA. Whether nucleosome strings provide a combinatory histone code is a matter of debate $[9,11,12,48$, 60-62], but in any event, histone modifications influence gene activity and regulation. For example, acetylation of lysines is generally associated with transcriptional activation whereas lysine methylation can dictate either activation (e.g. H3K4, H3K36, H3K79) or suppression (e.g. H3K9, H3K27 or H4K20). Specific histone modifications have been shown to be associated with DNA hypermethylation of $\mathrm{CpG}$ islands, including deacetylation of histones $\mathrm{H} 3$ and $\mathrm{H} 4$, loss of $\mathrm{H} 3 \mathrm{~K} 4 \mathrm{me}$, and gain of H3K9me3 and H3K27me3 [63, 64]. More importantly, specific histone modifications have been implicated in several diseases, such as cancer and CVD, while recently, evidence for modifications in allergic asthma and COPD is also emerging [21, 25, 65-68]. DNA methylation marks are recognized by DNA methylbinding proteins (MBD) which can interact with corepressor-associated enzymes (i.e. HDACs, enhancer of zeste homologue $(\mathrm{EZH}) 2, \ldots)$, thus further linking DNA methylation and chromatin regulation [43, 69]. Altogether, "histone code" may only become biologically meaningful at the level of the chromatin fiber ("chromatin regulatory code") which, upon integration of conformations of multiple nucleosomes, translates allosteric changes into specific gene (cluster) activities, in order to establish specific regulatory programs at the genome level [11, 70-72]. In analogy to allosteric control of enzymes, specific gene activity may be determined by the spatial organization (compartmentalization in discrete territories) and structural landscape (three-dimensional structure) of a gene locus, by altering the higher order structure of chromatin (cis mechanism) or by generating a binding platform for effector proteins (trans mechanisms) [70, 71, 73, 74].

There is good evidence that also noncoding RNAs regulate chromatin architecture [12, 7580]. The term noncoding RNA (ncRNA) is commonly employed for RNA that does not encode a protein. Although it has been generally assumed that most genetic information is transacted by proteins, recent evidence suggests that the majority of the genomes of mammals and other complex organisms is in fact transcribed into ncRNAs, many of which are alternatively spliced and/or processed into smaller products. Besides tRNA and rRNA, these ncRNAs include long-noncodingRNAs (lncRNAs), microRNAs (miRNAs) and tinyRNAs (tiRNAs) as well as several other classes of, sometimes yet-to-be-discovered, small regulatory 
RNAs such as snoRNAs [75-77]. These RNAs (including those derived from introns) appear to comprise a hidden layer of internal signals that control various levels of gene expression in physiology and development, including chromatin architecture/epigenetic memory, transcription (enhancer function), RNA splicing, editing, translation and turnover [81]. RNA regulatory networks may determine most of our complex characteristics and play a significant role in disease [81]. For example, miRNAs can change expression levels of the epigenetic machinery (DNMT, HDAC, sirtuin (SIRT), polycomb (Pc) proteins, etc.) by posttranscriptional gene regulation involving base pairing with 3'untranslated (UTR) regions in their target mRNAs resulting in mRNA degradation or inhibition of translation $[12,18,19$, 82]. Alternatively, long ncRNAs and tiRNAs can regulate gene expression and/or DNA methylation by promoter association [75, 76, 81]. DNA-methylation can thus also be RNAdirected $[12,83]$.

\section{Inflammatory and metabolic stress fuel epigenetic plasticity}

Inflammation is a fundamental adaptation to the loss of cellular and tissue homeostasis covering many important processes, including host defense, tissue remodeling and repair, and the regulation of metabolism. The complexity of the inflammatory response requires that its many functional programs are controlled coordinately in some situations but independently in others $[84,85]$. This is achieved through multiple mechanisms that operate at different levels, including alterations in the composition of immune cells in tissues, changes in cell responsiveness to inflammatory stimuli, regulation of signaling pathways and epigenetic control of gene expression.

Cell-specific mechanisms operate at the level of different cell types, and include regulation of their recruitment and activation. The cellular component involves the movement of leukocytes from blood vessels into the inflamed tissue, while leukocytes are involved in the initiation and maintenance of inflammation $[84,86]$. Macrophages participate in host defense, immunity and inflammatory responses, where they are potently activated resulting in the production of pro-inflammatory cytokines, oxygen and nitrogen species and eicosanoids. Acute inflammation is mediated by granulocytes or polymorphonuclear leucocytes, while chronic inflammation is mediated by mononuclear cells such as monocytes and macrophages which can be further stimulated to maintain inflammation through the action of an adaptive cascade involving dendritic cells, T- and B-lymphocytes and antibodies [84, 87-92]. Imbalances in control of haematopoesis and lineage differentiation of Th1, Th2 and Treg cells have a major impact on prevalence of sensitization to allergens and allergic diseases and has 
reached epidemic proportions in Western societies [93-96]. Furthermore, tumors are typically infiltrated with immune cells and inflammation which impacts on most, if not all, stages of tumorigenesis [97-100]. Moreover, most cancers contain an inflammatory infiltrate that is hijacked by tumor cells to promote angiogenesis, tissue invasion and cell proliferation. What is more, overnutrition and obesity activate the immune system which at long-term switches to chronic inflammatory condition that is as fertile soil for cancer development [3, 101-106]. Signal-specific mechanisms operate at the level of pathways which for example activate the key transcription factor nuclear factor- $\mathrm{\kappa B}(\mathrm{NF \kappa B})$. Among all the mediators and cellular effectors of inflammation, $\mathrm{NF \kappa B}$ is perhaps the central transcription factor, which regulates expression of more than 400 genes [107-109]. At the same time, it is responsible for many aspects of inflammatory disease and malignancy by inducing transcription of soluble mediators that amplify inflammation, angiogenesis and neoplastic cell proliferation, and affect progression to more aggressive disease states [97]. Members of the NFkB family of dimeric transcription factors (TF) regulate expression of a large number of genes involved in immune responses, inflammation, metabolic stress, cell survival, and cancer. NFkB family TF are rapidly activated in response to various stimuli, including cytokines, infectious agents, overnutrition (metabolic stress, endoplasmic reticulum stress) or danger signals (bacteria, viruses, chemicals, pathogen associated molecular patterns (PAMPs), danger associated molecular patterns (DAMPs), and radiation-induced DNA double-strand breaks. In nonstimulated cells, some NFkB TFs are bound to inhibitory (I) $\kappa \mathrm{B}$ proteins and are thereby sequestered in the cytoplasm. Activation leads to phosphorylation of IkB proteins and their subsequent recognition by ubiquitinating enzymes. The resulting proteasomal degradation of I $\mathrm{B}$ proteins liberates $\mathrm{NF} \kappa \mathrm{B} T \mathrm{TF}$, which translocate to the nucleus to drive expression of target genes. Two protein kinases with a high degree of sequence similarity, IкB kinase (IKK) $\alpha$ and IKK $\beta$, mediate phosphorylation of IKB proteins and represent a convergence point for most signal transduction pathways leading to $\mathrm{NF \kappa B}$ activation. Most of the IKK $\alpha$ and IKK $\beta$ molecules in the cell are part of IKK complexes that also contain a regulatory subunit called IKK $\gamma$ or NFkB-essential modulator (NEMO). Several years ago, two IKK-related kinases, called IKK $\varepsilon$ and TBK1 (TANK-binding kinase), were identified that exhibit structural similarity to IKK $\alpha$ and IKK $\beta$ [110]. Together, the IKKs and IKK-related kinases are instrumental for inducible activation of the host defense system and controlling metabolic stress [103, 105, 107, 111, 112]. Alternative to IKK, various additional kinases have been identified which modulate transcriptional nuclear activity of $\mathrm{NF \kappa B}$, including mitogen- and stress-activated protein kinase (MSK), protein kinase (PK)Ac, phosphoinositide 3-kinases 
PI3K and AKT [109, 113-116]. Furthermore, constitutive activity of NFאB/IKK has been observed in many cancer cells, inflammatory disorders, obesity and insulin resistance [102, $103,105-108,112,117-119]$. During obesity, the organism needs to adapt to and function under chronic exposure to high energy and nutrient intake. To cope with these challenges, the cell has developed the endoplasmic reticulum (ER) as a key nutrition sensor of cellular metabolic parameters (hyperglycemia, fatty acid overload, hypoglycemia, oxidative stress), which participates in viruatlly all anabolic and catabolic branches. Failure of the ER's adaptive capacity results in activation of the unfolded protein resonse (UPR), which intersects with many different inflammatory and stress signaling pathways at the crossroad of inflammation, cancer and metabolic disease $[17,105,106]$.

Gene-specific mechanisms operate at the level of individual genes and gene subsets. Induction of inflammatory transcriptional responses is orchestrated by many transcription factors and extragenic noncoding RNAs acting on inflammatory enhancers consistent with the complexity of the response [120-124]. Controlled expression of cytokine genes is an essential component of an immune response and is crucial for homeostasis. In order to generate an appropriate response to metabolic stress or an infectious condition, the type of cytokine, as well as the cell type, dose range and the kinetics of its expression are of critical importance [125-127]. The NFKB family TF has a crucial role in rapid responses to metabolic stress and pathogens (innate immunity), as well as in development and differentiation of immune cells (acquired immunity). Although quite a number of genes contain NFKB-responsive elements in their regulatory regions, their expression pattern can significantly vary from both a kinetic and quantitative point of view $[10,84,107,112,125,128-131]$. At the transcription level, selectivity is conferred by the expression of specific $\mathrm{NF \kappa B}$ subunits and their respective posttranslational modifications, and by combinatorial interactions between NFkB and other transcription enhancer factors (for example interferon regulatory factor (IRF)3, activating transcription factor (ATF)3, cAMP response element-binding protein CREB, CCAATenhancer binding protein C/EBP, activator protein (AP)1 (i.e. jun, fos, Fra1), Sp1, Stat3, PU.1) $[109,121,132]$. In addition to $\mathrm{NF \kappa B}, \mathrm{AP} 1 \mathrm{TF}$ are closely involved in inflammatory disease and cancer invasive gene expression programs [133, 134]. Inflammatory transcription factors can be divided into different categories on the basis of their mode of activation and function [84]. Primary response transcription factors are constitutively expressed by many celltypes in the cytoplasm and are activated by signal-dependent posttranslational modifications, which involves their nuclear translocation, such as NFkB, IRF, CREB. This TF are mainly responsible for the primary phase of gene induction and integrate signals from 
diverse signaling pathways which can amplify or terminate signal-dependent transcription factor activation. Another class TF requires de novo synthesis following inflammatory stimulation, for example $\mathrm{C} / \mathrm{EBP} \delta$. Most are constitutively nuclear and regulate secondary waves of gene expression. A third class of constitutively nuclear TF are expressed in a cell type-specific and differentiation-dependent manner, such as Runx, PU.1, IRF8, AP1, C/EBP $[121,128]$. They establish cell type-specific patterns of gene expression and are involved in chromatin remodelling during cell differentiation and organization of higher-order chromatin structure and chromosomal domains. The transcription factors of these TF categories do not act independently, but function coordinately to control the inflammatory transcriptional response. Upon combining datasets of expression profiling of inflammatory genes and in silico motif scanning of promoters of these genes they can define gene clusters that are coordinately regulated and the transcription factors that are likely to control their expression $[10,84,107,109,112,125,128-131]$. Since TF bind very poorly or not at all to nucleosomal DNA, their activation is coordinated to recruitment of ATP-dependent chromatin-remodeling factors (swith/sucrose non fermentable (SWI/SNF), Brahma (Brm), brahma-related gene, (Brg1)), histone-enzyme complexes such as kinases (IKK, MSK, ataxia telangiectasia mutated (ATM), AKT, PI3K), poly(ADP-ribose) polymerase (PARP), methylases (EZH2, coactivatorassociated arginine methyltransferase $(\mathrm{CARM}) 1$, protein arginine methyltransferases (PRMT)), demethylases (lysine specific demethylase (LSD)1, Jumonji C family histone demethylase (JMJD)3), prolyl isomerase (PIN1), acetylases (p300, CREB binding protein (CBP), p300/CBP associated factor (p/CAF)), deacetylases (HDAC, SIRT) and DNMTs [10, 43, 107, 114, 135, 136]. Parallel posttranslational modifications (phosphorylation, acetylation, methylation, ribosylation, sumoylation, ubiquitination) of histone and non-histone TF and cofactor complexes allow formation of dynamic enhanceosome complexes which establish a distinct chromatin structure. These epigenetic settings are the ultimate integration sites of both environmental and differentiative inputs, determining proper expression of each inflammatory gene $[10,107,131,137,138]$.

Further investigation of epigenetic regulation of inflammatory genes, revealed different different subclasses according to chromatin activation mode and gene expression profile [128, 139]. A major class of primary response genes is characterized by $\mathrm{CpG}$-island promoters, which facilitate promiscuous induction from constitutively active chromatin without a requirement for SWI/SNF nucleosome remodeling complexes. The low nucleosome occupancy at promoters in this class can be attributed to the assembly of CpG-islands into unstable nucleosomes, which may lead to SWI/SNF independence. Another major class 
consists of non-CpG-island promoters that assemble into stable nucleosomes, resulting in

SWI/SNF dependence and the requirement for transcription factors that promote selective nucleosome remodeling. Some inflammatory stimuli such as TNF, exhibit a strong bias toward activation of SWI/SNF-independent CpG-island genes. In contrast interferon (IFN) $\beta$ preferentially activates SWI/SNF-dependent non-CpG-island promoters. Interestingly, by activating a diverse set of transcription factors, Toll like receptors (TLR) induce both classes and others for an optimal response to PAMPs and DAMPs [128]. Remarkably, DNA methylation of IKK, IKB and RelB promoters [140-142] adds another regulatory control level which can act as transcription memory for repetitive pulsatile inflammatory exposures (endotoxin sensitization versus tolerance) [140, 143-146].

\section{Chronic inflammatory disorders and epimutations: cause or consequence?}

Since inflammatory gene expression dynamics is highly dependent on epigenetic control mechanisms [10, 84, 92, 120, 125, 137], we have compared chromatin organization in weak or strong inflammatory cancer cell types with inducible or constitutive interleukin (IL)6 gene expression patterns. Upon investigation of autocrine IL6 gene expression production in aggressive myeloma cells or metastatic breast cancer cells, we observed euchromatin-like properties and highly accessible chromatin at the IL6 gene promoter [133, 147]. Furthermore, recruitment of $\mathrm{CBP} / \mathrm{p} 300$ acetylases and MSK kinase seems to prevent heterochromatinisation and recruitment of heterochromatin protein (HP)1 upon phosphacetylation of transcription factor and histone components $[114,115,132,133,148]$ (See Figure 2). Interestingly, promoter binding activity of Sp1 and AP1 Fra1 are responsible for priming IL6 promoter chromatin relaxation, which further promotes binding of $\mathrm{NF \kappa B}$ transcription factors and chromatin opening for maximal expression levels [133, 147]. Interestingly, complementation of low invasive cancer cells with Fral seems to convert the promoter chromatin architecture in a highly accessible chromatin configuration. Reciprocally, highly accessible chromatin in invasive cancer cells can be silenced with anti-inflammatory phytochemicals, or following silencing of $\mathrm{AP} 1 / \mathrm{NF \kappa B}$ transcription factors, demonstrating reversible epigenetic changes towards a less aggressive phenotype [133, 149, 150]. Along the same line, we and others observed DNA hypermethylation at the IL6 gene promoter in cancer cells with low NFאB/AP1 activity and inducible IL6 gene expression, as compared to DNA hypomethylation in cancer cells with hyperactivated NFKB/AP1 transcription factors and elevated constitutive IL6 gene expression ([151, 152] and Figure 2). Similarly, p53 knockout cells reveal defects in genomic imprinting and DNA methylation regulation [153] As such, this demonstrates that 
inflammatory signaling and transcription factors are able to rewire epigenetic settings and amplify gene expression in an autocrine fashion [46, 154]. As another example, DNA methylation of the NFkB responsive element in the Fas (CD95, Apo-1, TNFRSF6) gene promoter, was found to silence its expression in metastatic prostate carcinoma $[46,155]$. Surprisingly, depletion of NFKB can also trigger DNA demethylation and gene reactivation of the Fructose-1,6-biphosphatase-1 (FBP1) illustrating gene-specific epigenetic effects which may further depend on posttranslational NFkB modifications $[136,156]$.

Of special note, whereas studies with epigenetic drugs (azacytidin, suberoylanilide hydroxamic acid (SAHA)) frequently focus on reactivation of silenced tumor suppressor genes, these compounds also boost gene expression of inflammatory oncogenes such as IL6 which promote aggressive carcinogenesis, cancer stem cell proliferation, metastasis and hormone resistance [100, 157-164]. Furthermore, elevated IL6 gene expression is able to trigger epigenetic changes of tumor suppressor genes via regulation of DNMTs [165-168], microRNAs [158, 169, 170] and histone methyltransferases (Ezh2) [171]. This suggests that epigenetic regulators themselves and methylation of tumor suppressor genes are also susceptible to dynamic inflammatory control [158, 165, 169, 170, 172-175], which adds an extra level of complexity to the cancer-inflammation link.

Furthermore, besides epigenetic changes in neoplastic cells, inflammatory stimuli in the tumor microenvironment can also epigenetically reprogram tumor-associated immune cells, as demonstrated for the NFKB-dependent histone demethylase JMJD3 which determines cell fate and transdifferentiation of tumor-associated macrophages [120, 176]. Reports on epigenetic events in cancer are traditionally produced from analyses on "bulk" tumor samples, i.e. without distinction between neoplastic cells on one hand and the tumoral stroma on the other. The pro-inflammatory micro-environment that drives many tumor types is as such capable of triggering these epigenetic alterations within cancer progenitor cells, alterations which can substitute for genetic defects later in tumour progression [158, 177]. However, also tumor stromal components (which include bone-marrow-derived cells, tumor-associated macrophages) are a target of epigenetic events [92, 120, 149]. Similarly, in atherosclerotic plaques, interplay between monocytes, macrophages and vascular endothelium will trigger various epigenetic alterations in the different cell types in the plaque microenvironment [68, 178-185]. Besides inflammatory factors, the micro-environment also contains free radicals produced by neutrophils, macrophages, endothelial and other cells. Reactive Oxygen Species (ROS) such as ${ }^{\circ} \mathrm{O}_{2},{ }^{\circ} \mathrm{OH}, \mathrm{H}_{2} \mathrm{O}_{2}$, NO and ${ }^{1} \mathrm{O}_{2}$ can injure cellular biomolecules such as nucleic acids, enzymes, carbohydrates, and lipid membranes, causing cellular and tissue damage, 
which in turn augments the state of inflammation. In addition, reactive nitrogen intermediates such as NO and ROS, indirectly also modulate activity of epigenetic machinery which finally will affect chromatin dynamics in tumor-associated immune cells [186-190].

One of the key functional characteristics of macrophages is that they can be programmed to deal most effectively with a given kind of inciting stimulus. In the lung for example, resident alveolar macrophages are continuously encountering inhaled substances due to their exposed position in the alveolar lumen [93]. To avoid collateral damage to mucosal epithelium in response to harmless antigens, they are kept in a quiescent state, producing little inflammatory cytokines and displaying poor phagocytic activity. In the vessel wall, macrophages can scavenge large amounts of lipid, and differentiate into lipid-laden foamy cells [179]. As putative precursors for microglia and osteoclasts, monocytes may also be involved in the physiology of the central nervous system and in bone remodelling. Dendritic cells (DC) are also part of the monocytic phagocytic system and are the professional antigen presenting cells of the immune system that bridge innate and adaptive immunity [91]. DC cells come in many flavours and it is clear now that there are multiple pathways to develop DC from monocytes. The complexity of the monocytic phagocytic system requires that its many functional programmes are controlled coordinately in some situations, but separately in others. It is now clear that epigenetic mechanisms can lead to time-dependent and stimulus-specific alterations in the expresssion of functional modules [191]. Epigenetic modifications like histone modifications and $\mathrm{CpG}$-island methylation in promotor regions of critical transcription factors (so called masterswitch transcription factors) of all of these functional programmes have been described and are controlled by microRNAs, DNMTs, HDAC, histone acetylases (HAT $\mathrm{CBP} / \mathrm{p} 300, \mathrm{p} / \mathrm{CAF}$ ) histone lysine methylases (EZH2, CARM, PRMT) and demethylases (LSD1, JMJD3) [192, 193]. Emerging research indicates that epigenetic mechanisms that control the lineage development and polarization of monocytic phagocytic system and Th1, Th2 and Treg cells can be transmitted across multiple generations [84, 89, 194, 195]. Smoking, diesel exhaust, diet conditions, hygiene, dust mite, obesity seem have major influence on epigenetic programming of immune cell populations and inflammatory disease severity in asthma, allergy, rheumatoid arthritis, bowel disease [196-202]. Similarly, hypertension, obesity and lack of physical activity can have longlasting effects on epigenetic reprogramming of monocytes/macrophages and endothelial cells promoting differentiation into more proatherogenic phenotypes and increased risk of cardiovascular disease $[68,180$, 182-185, 203]. 


\section{Nutri-epigenomics: lifelong remodelling of our epigenomes by nutritional,} phytochemical and metabolic factors

Human epidemiological studies and appropriately designed dietary interventions in animal models have provided considerable evidence to suggest that maternal nutritional imbalance and metabolic disturbances, during critical time windows of development, may have a persistent effect on the health of offspring and may even be transmitted to the next generation [29, 32, 204-208]. This has led to the hypothesis of "fetal programming" and new term "developmental origin of health and disease" (DOHaD): common disorders, such as obesity, cardiovascular disease (CVD), diabetes, hypertension, asthma, cancer and even schizophrenia, take root in early nutrition during gestation and continues during lactation [28, 32, 209-214]. The various non-Mendelian features of metabolic disease, cancer or chronic inflammatory disorders, clinical differences between men and women or monozygotic twins and fluctuations in the course of the disease are consistent with epigenetic mechanisms in the influence of fetal and/or lifelong nutrition or stochastic events on adult phenotype [29, 32, 204-208, 215, 216]. Thus, lifetime shapes the multitude of epigenomes not only within, but also across generations [29, 207]. Interest in transgenerational epigenetic effects of food components has been fueled by observations in Agouti mice fed with a soy polyphenol diet, which revealed epigenetic changes in DNA methylation patterns in their offspring and protected against diabetes, obesity and cancer across multiple generations [217-219]. However, only weak transgenerational effects could be observed with soy polyphenols in Daphnia Magna, despite the presence of functional DNMTs [220]. Feeding pregnant mice with a diet rich in methyl donors altered DNA methylation at well defined $\mathrm{CpG}$ regions which led to decreased transcription of Runx 3 and more sever asthma in offspring. Bronchial biopsies and alveolar macrophages of asthmatics revealed a disturbed epigenetic regulation of gene expression (increased HAT and decreased HDAC2 activity) [221]. Furthermore, the honeybee (Apis mellifera) is probably the clearest example of induction of alternative phenotypes and epigenotypes by nutrition in early life [222]. Female bees are genetic clones. However, queens are distinct from workers in their morphology, capacity to reproduce, behavior, and longevity. The difference between the queen and worker castes lies in the exposure of the genetically identical larvae to royal jelly, an as yet incompletely defined mixture of proteins, amino acids, vitamins, lipids, and other nutrients [223-225].

Studies of human populations following famine have suggested that pathologies in later life are dependent on the timing of nutritional insult during pregnancy. Follow up of the Dutch Hunger Winter cohort showed that cardiovascular disease was more prevalent in offspring of 
mothers who were severely undernourished during the first trimester of their pregnancies in 1944-1945, as compared to those born to mothers whose pregnancies were more advanced at the time of nutrional insult [226-228]. Also paternal patterns of nutrition during the prepubertal growth period in children in Överkalix, in Sweden during the nineteenth century are associated with differential risk of early cardiovascular death in their grandchildren [229, 230]. Today, various different epigenetic changes have already been characterized which are involved in atherogenesis [28, 29, 65, 67, 231]. Hypercholesterolemia, obesity, hyperhomocysteinemia, high glucose are important CVD risk factors which are implicated in enhanced inflammatory signaling and long-lasting effects are driven by epigenetic reprogramming, promoting differentiation of monocytes/macrophages into more proatherogenic phenotypes $[68,181,182,232]$. Recent evidence suggests that the pathogenetic role of hyperhomocysteinemia in vascular diseases might be mediated via Adenosyl-homocystein (Hcy) accumulation and DNA methylation. Hcy competes with Sadenosylmethionine (SAM; the methyl-group donor) for binding on DNMT, which may lead to passive loss of methylation in replicating DNA. High blood Hcy levels correlate with DNA hypomethylation and atherosclerosis and can lead to a 35\% reduction in DNA methylation status of peripheral blood lymphocytes [233-236]. Similarly, insulin, glucose folate or flavanol-rich diets interfere with the methyldonor metabolism and the available pool of Sadenosylmethionine, resulting in DNA methylation changes [236-239]. In contrast, very few studies have focused on impact of dietary methyldonors on histone methylation, which is also affected by alterations in SAM/SAH ratios [233, 240]. As such, specific dietary classes of functional food maybe designed as therapeutic epigenetic modulators in lifestyle disease, such as metabolic disorders (diabetes), cardiovascular disease, asthma/COPD, rheumatoid arthritis. Epidemiologic and medical anthropological studies have indicated that flavanol-rich diets are inversely associated with cardiovascular risk [241-246]. Locus-specific DNA methylation changes, both hyper- and hypomethylation, also occur at the promoter level of several genes involved in the pathogenesis of atherosclerosis, such as extracellular superoxide dismutase (SOD), hormone receptors (glucocorticoid receptor (GR), estrogen receptor (ER), peroxisome proliferator-activated receptor (PPAR), arylhydrocarbon receptor, AhR, liver X receptor (LXR)), endothelial and inducible nitric oxide synthase (iNOS/eNOS), 15-lipoxygenase (LOX), fibroblast growth factor (FGF)2, hypoxia-inducible factor (HIF) $1 \alpha$, myc, insulator CCCTC binding factor (CTCF) and metalloproteases (MMPs) [68, 183, 247-249]. In a proatherogenic murine model, DNA-methylation polymorphisms preceded the appearance of histological signs of atherosclerosis [181, 182]. Interestingly, involvement of the inducible 
JMJD3 demethylase was demonstrated to regulate monocyte/macrophage transdifferentiation programs, illustrating that developmental programs are plastic and monocyte lineage differentiation is susceptible to inflammatory pathways and oxidative stress [120]. A role for the JMJD1A demethylase was demonstrated in metabolic gene expression and obesity resistance [250]. Furthermore, it was found that knockdown of the LSD1 demethylase affected monocyte adherence in a proatherogenic diabetic mouse model [251]. This suggests that LSD1 contribute to metabolic memory through long-term changes in gene expression via alterations in chromatin structure [146, 252].

Poor maternal nutrition has also been associated with increased risk of type 2 diabetes mellitus over several generations in North American Indians [253, 254]. Individuals with metabolic syndrome, obesity and type II diabetes (T2D) CVD may show a lifelong imbalance between energy intake and energy expenditure due to incorrect epigenetic programming during their early development as a result of placental insufficiency, inadequate maternal nutrition, metabolic disturbances or neonatal medication [205, 253-258].

Recently, evidence emerged that also timing (preconception, pregnancy, lactation, neonatal life, early life, pre-/post-menopause, puberty) of various dietary exposures may be vitally important in determining health beneficial effects, as epigenetic plasticity changes continually from conception to death [259]. In principle; epigenetic changes occurring during embryonic development will have a much greater impact on the overall epigenetic status of the organism because, as they can be transmitted over consecutive mitotic divisions, alterations occurring in single embryonic stem cells will affect many more cells than those occurring in adult stem and /or somatic cells during postnatal development [206]. Epigenetic plasticity further also depends on other processes such as chromosomal instability, telomere shortening, metabolic cycles, mitochondrial deteriorations, and oscillatory, circadian or seasonal rhythms of systemic hormone levels (hypothalamic-pituitary-adrenal (HPA) axis) [28-30, 258-262]. In addition to epigenetic imprinting during crucial periods of development, stochastic or genetically and environmentally triggered epigenomic changes (epimutations) occur day after day and accumulate over time, as maximal differences in DNA methylation profiles are observed in aged monozygotic twins with a history of non-shared environments [6, 8]. Concerning nutritional transgenerational inheritance there is increasing evidence in both plants and animals that, following nutritional intervention (caloric, iron and protein restriction, polyphenol-, folate-, micronutrient-, fat- or carbohydrate-rich diet), maternal diabetes, during pregnancy and lactation can affect the following generation(s) $[38,207,211$, 218, 219, 263, 264]. Although it has long been thought that the epigenomic profile is wiped 
clean in the embryo shortly after fertilization, with the exception of imprinted genes, methylation clearing is not complete after fertilization and on a global DNA level is reduced to $10 \%$ [265, 266]. Alternatively, it can not be excluded that transgenerationally inherited nutritional effects may also depend on polycomb proteins [207, 267-269], miRNA profiles [12, 270] or epigenetic capacitor properties of hsp proteins [271-273].

A next challenge will be to determine which adverse epigenomic marks are reversible by specific diets, drugs or lifestyle changes [29, 32, 38, 259]. Numerous botanical species and plant parts contain a diverse array of polyphenolic phytochemicals which exert healthbeneficial effects in man by its anti-inflammatory, anti-oxidant, phytohormone, cardioprotective, cancer preventive and anti-bacterial properties, by maintaining immune homeostasis (hormesis) [274, 275]. Phytochemicals have also succesfully been applied for regenerative medicine and cancer stem cell therapy [173, 276-280]. Oxidative stress and inflammatory damage plays an important role in epigenetic reprogramming of expression of cytokines, oncogenes and tumor suppressor genes, thereby setting up a ground for chronic inflammatory diseases and carcinogenesis [97, 100, 281]. As such chemoprevention, the strategy to inhibit, retard, or even reverse the epigenetic stage of chronic inflammation is one of the most rational approaches to reduce the global burden of non communicable lifestyle diseases [3, 100, 211]. Today, various nutritional natural compounds (including epigallocatechingallate, resveratrol, genistein, curcumin, isothiocyanates ...) have been characterized which interfere with enzymatic activity of DNMT, Class I, II, IV HDAC, HAT and Class III HDAC sirtuins (SIRT) which modulate inflammatory responses and immunological senescence ([32-41, 213, 282] and references included, see Table 1). HDACs are zinc metalloproteins which rely on $\mathrm{Zn}^{2+}$ for their activity and are divided into 4 classes based on their homology with yeast HDACs. Class III HDACs, called sirtuins are zincindependent but nicotinamide adenine dicnucleotide $\left(\mathrm{NAD}^{+}\right)$-dependent. Class I, II, IV HDAC inhibitors characteristically contain a $\mathrm{Zn}^{2+}$ chelating group consisting of a thiolate, thiol, hydroxamate, carboxylate, mercaptoamide, epoxide or ketone group. Natural HDAC inhibitors can be divided in following groups based on their chemical characteristics: carboxylates, organosulfides, isothiocyanates, hydroamates, cyclic tetrapeptides and macrocyclic depsipeptides [35]. In contrast to natural HDAC inhibitors, only few natural products (i.e. niacine, vitamin B3, dihydrocoumarin) have been identified as inhibitors of class III HDACs. Reciprocally, various natural flavonoids have been identified as activators of class III HDACs (SIRTs). Finally, turmeric and green tea have been identified as sources of natural inhibitors of p300/CBP HAT. Finally DNMT inhibitors work mainly through one of 
the following mechanisms, either covalent trapping of DNMT through incorporation into DNA (i.e. nucleoside analogues decitabine, 5-azacytidine), non-covalent blocking of DNMT catalytic active site (i.e. EGCG, parthenolide), interruption of binding site of DNMT to DNA (i.e. procaine), degradation of DNMT (i.e; decitabine), or suppression of DNMT expression (i.e. miRNAs). Furthermore, a number of natural compounds act as multifunctional ligands by simultaneously acting on nuclear hormone receptors and changing activity of histone modifying enzymes and DNMTs [283-287]. Of special note, although health protective antioxidant or anti-inflammatory effects of dietary factors and extracts have frequently been demonstrated in in vitro experiments at concentrations which can never be achieved in vivo, "epigenetics" sheds a more realistic light on dietary studies, as longlife exposure at physiological concentrations can remodel the epigenome in a cumulative fashion by repetitive effects on the epigenetic machinery [241, 288-291]. Particular attention needs to be given to natural compounds which can trigger opposite effects on HDAC/HAT/DNMT or histone (de)methylase (H(D)MT) depending on the concentration or cell type-specific metabolisation $[34,35]$. It should also be stressed that it is not known whether all of them can be considered authentic epigenetic modifiers because it has not yet been demonstrated whether the epigenetic modifications that they induce are stable over time. Interestingly, even transient exposure to a specific dietary component can induce long-lasting epigenetic changes in the promoter of the NFkB subunit p65, which acts as a master switch in inflammatory gene expression [146]. Alternatively, compounds may chemically interfere with histone mark interacting effector domains (such as chromo-, bromo- or tudor domains) [47, 292, 293]. However, one should be careful with interpretation of in vitro compound screenings or cofactor activity assays based on peptide-protein interactions, as this may not always represent true targets in vivo [294, 295].

Besides specific interference of the diet with chromatin modifying enzymes and DNMTs at particular target genes, global epigenetic changes can also occur following biochemical metabolisation of dietary factors, which can deplete cellular pools of acetyl-CoA, $\mathrm{NAD}^{+}$and methyldonors, resulting in unbalanced DNA methylation and/or protein acetylation or methylation [282, 296, 297]. For example diets lacking in substrate or cofactors in methyldonormetabolism can contribute to DNA hypomethylation by impairing synthesis of SAM [234]. This methylation cycle is frequently cited to explain relations between diet and epigenetic changes [233, 298]. However, even without nutritional deficiency of methyl groups, impaired synthesis of SAM and perturbed DNA methylation can happen when the need for the synthesis of the detoxification enzyme glutathione transferase (GSH) synthesis 
increases [299]. Diets or nutritional compounds which affect energy metabolism or mitochondrial respiration can have global epigenetic effects upon changes in $\mathrm{NAD}^{+}$ availability and SIRT activity [300]. Since SIRT activation has been linked to longevity (increased lifespan and healthy aging) and mimics a caloric restricted diet, SIRT activators such as resveratrol represent a major class of caloric mimetic epigenetic modulator phytochemicals which could reverse metabolic disease [297].

\section{Conclusion}

The phenotype of an individual is the result of complex gene-environment interactions in the current, past and ancestral environment, leading to lifelong remodelling of our epigenomes. In recent years, several studies have demonstrated that disruption of epigenetic mechanisms can alter immune function and and that epimutations not only contribute to various cancers but also to the development of diabetes, allergy, CVD and rheumatoid arthritis. Various replication-dependent and -independent epigenetic mechanisms are involved in developmental programming, lifelong recording of environmental changes and transmitting transgenerational effects. It is likely that understanding and manipulating the epigenome, a potentially reversible source of biological variation, has great potential in chemoprevention or stabilization of chronic inflammatory disorders. Much attention is currently focusing on modulating hyper/hypomethylation of key inflammatory genes by dietary factors as an effective approach to cure or protect against inflammatory disease [32-41, 213, 282]. In this respect, "Let food be your epigenetic medicine" could represent a novel interpretation of what Hippocrates said already 25 centuries ago. As such, it will be a challenge for future antiinflammatory therapeutics and preventive cancer research to identify novel epigenetic targets which allow selective modulation of the inflammatory signaling network in the diseased tissue and/or microenvironment [275, 301-306]. Given several encouraging trials, prevention and therapy of age- and lifestyle-related diseases by individualised tailoring of optimal epigenetic diets or supplements are conceivable. However, these interventions will require intense efforts to unravel the complexity of these epigenetic, genetic and environment interactions. Another goal is to evaluate their potential reversibility with minimal side effects as diet components may reprogram malignant cells as well as the host immune system and HPA-axis depending on the bioavailability of the dietary compounds $[32,133,149,150,289$, 291] (See Figure 3). There is some concern that epigenetic therapy with dietary inhibitors of DNMT, HDAC, histon(de)methylases in longterm treatment setups may suffer from lack of specificity [283, 292, 294]. As such, the possible alternative is to combine nonselective 
epigenetic therapies with more targeted approaches [46]. For example, combined treatment of specific transcription factor inhibitors and/or hormone receptor ligands with epigenetic drugs may trigger synergistic activities at subsets of inflammatory genes [43, 46, 307-309]. An excellent example of cooperation between a dietary vitamin A-derivative targeting a nuclear receptor and the HDAC inhibitor butyrate has been described in the treatment of acute promyelocytic leukemias [33]. Finally, microRNA and long ncRNA pathways also hold promise to join soon the arsenal of epigenetic combination therapies, as their target sequence specificity may bridge the gap between genetic and epigenetic changes [12, 79-81]. In conclusion, studies are revealing a dazzling complexity in the mechanisms leading to dynamic alterations of the epigenome and the need of combination therapies targeting different chromatin modifiers, to reverse disease prone epigenetic alterations to preserve healthy aging. Medical benefits of dietary compounds as epigenetic modulators, especially with respect to their chronic use as nutraceutical agents, will rely on our further understanding of their epigenetic effects during embryogenesis, early life, aging as well as through different generations.

\section{Acknowledgements}

This research is partially financial supported by FP7-KBBE-2008-2B grant FLAVIOLA ("Targeted delivery of dietary flavanol for optimal human cell function: Effects on cardiovascular health (www.flaviola.org)), Research Grant from the Multiple Myeloma Research Foundation (MMRF) and Interuniversity Attraction Poles (IAP) P6/18. We regret that not all literature could be cited appropriately because of space constraints and we apologize to those authors whose original work is not mentioned. 


\section{Figure 1}

Interplay of inflammatory and metabolic stress pathways in nutritional epigenetic effects in lifestyle diseases. mut, mutation; SNP, single nucleotide polymorphism; miR, microRNA, ncRNA, noncoding RNA.

\section{Figure 2}

Working model illustrating crosstalk of inflammatory and metabolic stress pathways with epigenetic regulation in the nucleus. For example, transcription of the highly conserved IL6 gene promoter requires binding of activator protein AP1, CREB and nuclear factor NFkB transcription factors in response to various stimuli [310, 311], with strict stereospecific requirements for optimal cofactor recruitment, promoting a promoter enhanceosome model with multiple transcription factor/cofactor interactions, in which $\mathrm{NF \kappa B}$ is the primary trigger for IL6 gene induction in response to TNF. Inflammatory stimuli (i.e. TNF, virus, bacteria) or metabolic stress (including oxidative stresss, endoplasmic reticulum (ER) stress or unfolded protein response (UPR) stress, for example during obesity or malnutrition) can activate the

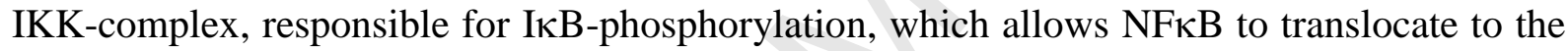
nucleus, following degradation of IאB in the proteasome. IL6 gene expression also requires activation and recruitment of the mitogen- and stress-activated protein kinase-1 (MSK1) to elicit selective chromatin relaxation at the IL6 gene promoter, upon phosphorylation of NFKB p65 S276 and histone H3 S10, followed by further CBP/p300 recruitment and HATdependent acetylation of the IL6 promoter enhanceosome/chromatin environment [115]. Highly elevated expression levels of AP1 Fra1 and NFאB in ER-deficient tumor cells increase chromatin accessibility (DNA hypersensitive sites) in the proximal IL6 gene promoter. Of particular interest, dietary anti-inflammatory phytochemicals such as soy polyphenol genistein $[149,150,274]$ and withanolide withaferin A [312] are able to silence the highly promiscuous IL6 promoter nucleosome configuration by lowering the cellular amounts of Fra1 and NFKB activity, concomitantly with decreased histone H3 phosphoacetylation levels and increased DNA methylation $[133,149,150]$.

\section{Figure 3.}

Flowchart which summarizes the complex and multilayered regulation of nutritional epigenetic effects. 
Table 1. Overview of nutritional epigenetic effects by dietary phytochemicals (summarized

from $[32-41,213,282]$ and references included). Suffix I, inhibitor; suffix a, activator, for example HDACi, HDAC inhibitor, or SIRTa, SIRT activator

\begin{tabular}{|c|c|c|c|c|c|}
\hline $\begin{array}{c}\text { Bioactive } \\
\text { Phytochemical }\end{array}$ & $\begin{array}{l}\text { Natural } \\
\text { Source }\end{array}$ & Disease Target & $\begin{array}{l}\text { Epigenetic } \\
\text { mechanism }\end{array}$ & In vitro / In vivo & $\begin{array}{c}\text { Target genes / } \\
\text { microRNAs }\end{array}$ \\
\hline $\begin{array}{l}\text { 3,3- } \\
\text { diindolylmethane }\end{array}$ & Broccoli & Cancer & $\begin{array}{l}\text { Decreased HDAC } \\
\text { levels }\end{array}$ & In vitro / in vivo & cOX2 \\
\hline $\begin{array}{l}\text { 6-methoxy-2E,9E- } \\
\text { humuladien-8-one }\end{array}$ & Ginger & Cancer & HDACi & In vitro & \\
\hline Allylmercaptan & Garlic & Cancer & HDACi & In vitro/in vivo & P21/WAF \\
\hline Anacardic Acid & Cashew nuts & Cancer, Leukemia & HATi & In vitro & +2 \\
\hline Apigenin & Parsley, celery & Cancer & DNMTi & In vitro & $+>$ \\
\hline Betanin & Beetroot red & Cancer & DNMTi & In vitro & $\nabla$ \\
\hline Biochanin A & Soy & Cancer & $\begin{array}{l}\text { DNMTi } \\
\text { HDACi }\end{array}$ & $\begin{array}{l}\text { In vitro / in vivo } \\
\text { Daphnia }\end{array}$ & \\
\hline Butyryc acid & $\begin{array}{l}\text { Fermentation } \\
\text { dietary fibers }\end{array}$ & Cancer & HDACi & In vitro / In vivo & \\
\hline Caffeic acid & Coffea & $\begin{array}{l}\text { Cancer } \\
\text { Inflammation } \\
\text { Energy metabolism }\end{array}$ & $\begin{array}{l}\text { DNMTi } \\
\text { HDACi }\end{array}$ & In vitro & RAR $\beta$, CDKN2A \\
\hline Catechin & Green tea & $\begin{array}{l}\text { Cancer } \\
\text { Lymphocytes }\end{array}$ & $\begin{array}{l}\text { DNMTi } \\
\text { HATi }\end{array}$ & In vitro & RAR $\beta$ \\
\hline Chlorogenic acid & Coffea & Cancer & $\begin{array}{l}\text { DNMTi } \\
\text { HDACi }\end{array}$ & In vitro & RAR $\beta$, CDKN2A \\
\hline $\begin{array}{l}\text { Coumaric acid } \\
\text { Cinnamic acid }\end{array}$ & Cinnamon & Cancer & $\begin{array}{l}\text { DNMTi } \\
\text { HDACi }\end{array}$ & In vitro / in vivo & \\
\hline $\begin{array}{l}\text { Coumarin } \\
\text { analogues } \\
\text { Dihydrocoumarin }\end{array}$ & $\begin{array}{l}\text { Melilotus } \\
\text { officinalis } \\
\text { (Sweet clover) }\end{array}$ & Cancer, Leukemia, & $\begin{array}{l}\text { SIRTi } \\
\text { p53 acetylation }\end{array}$ & In vitro & \\
\hline Curcumin & $\begin{array}{l}\text { Turmeric } \\
\text { (Curcuma } \\
\text { longa L.) }\end{array}$ & $\begin{array}{l}\text { Crohn's Disease, } \\
\text { Ulcerative colitis } \\
\text { Inflammatory disease } \\
\text { Cancer, Leukemia } \\
\text { Neurodegeneration } \\
\text { Alzheimer } \\
\text { Diabetes } \\
\text { Heart Failure } \\
\text { Epilepsy }\end{array}$ & $\begin{array}{l}\text { DNMTi } \\
\text { HATi } \\
\text { HDACi }\end{array}$ & $\begin{array}{l}\text { In vitro / In vivo } \\
\text { Plasmodium } \\
\text { falciparum, } \\
\text { Herpes Virus } \\
\text { Mouse } \\
\text { Rat }\end{array}$ & $\begin{array}{l}\text { GATA4, EOMES, } \\
\text { GZMB, PRF1 } \\
\text { Up: miR-22, miR-34a, } \\
\text { miR-24, miR-181a, } \\
\text { miR-21, miR-181b, } \\
\text { miR-27a } \\
\text { Down: miR-199a, miR- } \\
\text { 510, miR-196a, miR-7, } \\
\text { miR-15b, } \\
\text { miR-195, miR-374, } \\
\text { miR-98 }\end{array}$ \\
\hline Cyanidin & $\begin{array}{l}\text { Berries, } \\
\text { Grapes }\end{array}$ & Cancer & DNMTi & In vitro & \\
\hline Daidzein & Soy & Cancer & $\begin{array}{l}\text { DNMTi } \\
\text { SIRTa }\end{array}$ & In vitro & \\
\hline Diallyl disulfide & Garlic & $\begin{array}{l}\text { Inflammatory disease } \\
\text { Cancer }\end{array}$ & HDACi & $\begin{array}{l}\text { In vitro / in vivo } \\
\text { rat }\end{array}$ & p21/WAF \\
\hline Ellagic Acids & Berries & Cancer & DNMTi & In vitro & \\
\hline Epicatechin & $\begin{array}{l}\text { Apples, Cocoa, } \\
\text { Green and } \\
\text { black tea }\end{array}$ & $\begin{array}{l}\text { Inflammatory } \\
\text { disease, lymphocytes } \\
\text { Cancer } \\
\text { CVD }\end{array}$ & $\begin{array}{l}\text { DNMTi } \\
\text { HATi }\end{array}$ & In vitro & \\
\hline $\begin{array}{l}\text { Epicatechin } \\
\text { gallate }\end{array}$ & Green tea & $\begin{array}{l}\text { Cancer } \\
\text { Lymphocytes }\end{array}$ & $\begin{array}{l}\text { DNMTi } \\
\text { HATi }\end{array}$ & In vitro & \\
\hline Epigallocatechin & Green tea & $\begin{array}{l}\text { Cancer } \\
\text { Lymphocytes }\end{array}$ & $\begin{array}{l}\text { DNMTi } \\
\text { HATi }\end{array}$ & In vitro & \\
\hline $\begin{array}{l}\text { Epigallocatechin } \\
\text { 3-gallate (EGCG) }\end{array}$ & Green tea & $\begin{array}{l}\text { Inflammatory disease } \\
\text { Parkinson } \\
\text { Cancer, Leukemia } \\
\text { CVD }\end{array}$ & $\begin{array}{l}\text { DNMTi } \\
\text { HDACi } \\
\text { HMTi }\end{array}$ & $\begin{array}{l}\text { In vitro / In vivo } \\
\text { Agouti } \\
\text { Mouse/Human }\end{array}$ & $\begin{array}{l}\text { RAR } \beta, \text { MGMT, MLH1, } \\
\text { CDKN2A, RECK, TERT, } \\
\text { RXR } \alpha, \text { CDX2, GSTP1, } \\
\text { WIF1, NFkB, IL6, Bmi1, } \\
\text { Ezh2, Suz12 } \\
\text { Up : let-7, miR-16, }\end{array}$ \\
\hline
\end{tabular}




\begin{tabular}{|c|c|c|c|c|c|}
\hline & & $\begin{array}{l}\text { Diabetes } \\
\text { Energy metabolism }\end{array}$ & & & $\begin{array}{l}\text { miR-18b, miR-20a, } \\
\text { miR-25, miR-92, } \\
\text { miR-93, miR-221, } \\
\text { miR-320 } \\
\text { Down: miR-10a, miR- } \\
\text { 18a, miR-19a, miR- } \\
\text { 26b, miR-29b, } \\
\text { miR-34b, miR-98, } \\
\text { miR-129, miR-181d }\end{array}$ \\
\hline Equol & Soy & Cancer & $\mathrm{HDACi}$ & $\begin{array}{l}\text { In vitro / in vivo } \\
\text { Drosophila }\end{array}$ & \\
\hline Fistein & Strawberies & $\begin{array}{l}\text { Cancer } \\
\text { Inflammatory disease }\end{array}$ & SIRTa & In vitro & \\
\hline Flavone & Feijoa & Cancer & $\mathrm{HDACi}$ & $\begin{array}{l}\text { In vitro / in vivo } \\
\text { Drosophila }\end{array}$ & $\mathrm{p} 16, \mathrm{p} 21, \mathrm{TRAIL}$ \\
\hline $\begin{array}{l}\text { Folic Acid } \\
\text { Folate }\end{array}$ & $\begin{array}{l}\text { Leafy } \\
\text { vegetables, } \\
\text { Nuts, } \\
\text { Sunflower } \\
\text { seads }\end{array}$ & $\begin{array}{l}\text { Inflammatory disease } \\
\text { Asthma } \\
\text { Cancer } \\
\text { Obesity } \\
\text { CVD }\end{array}$ & $\begin{array}{l}\text { Induction of DNA } \\
\text { methylation }\end{array}$ & In vitro / In vivo & $\begin{array}{l}\text { Up : miR-10a, miR- } \\
\text { 10b, miR-9, miR-145, } \\
\text { miR-30a-3p, } \\
\text { miR-152, miR-122a, } \\
\text { miR-125b } \\
\text { Down: miR-200a, miR- } \\
\text { 496, miR-296, miR- } \\
\text { 30e-5p, miR-362, } \\
\text { miR-339, miR-29c, } \\
\text { miR-154, miR-10a }\end{array}$ \\
\hline Galangin & Propolis & Cancer & DNMTi & In vitro & \\
\hline Garcinol & Garcinia & $\begin{array}{l}\text { Cancer } \\
\text { HIV } \\
\text { Leukemia } \\
\text { Lymphocytes }\end{array}$ & $\begin{array}{l}\text { DNMTi } \\
\text { HATi }\end{array}$ & In vitro & $\begin{array}{l}\text { Global downregulation } \\
\text { gene expression }\end{array}$ \\
\hline Genistein & Soy & $\begin{array}{l}\text { Inflammatory disease } \\
\text { Cancer }\end{array}$ & $\begin{array}{l}\text { DNMTi } \\
\text { HATi } \\
\text { HDACi } \\
\text { Increase DNA } \\
\text { methylation } \\
\text { Changed protein } \\
\text { levels DNMTs, } \\
\text { MBD1, MBD4, } \\
\text { MeCP2 }\end{array}$ & $\begin{array}{l}\text { In vitro / In vivo } \\
\text { Agouti } \\
\text { Daphnids }\end{array}$ & $\begin{array}{l}\text { RAR } \beta \text {, MGMT, } \\
\text { CDKN2A, GSTP1, } \\
\text { HMGN5, BTG3, TERT } \\
\text { P21, p16,PTEN, CCLD, } \\
\text { p53, FOXA3, SIRT1, } \\
\text { BTG3, RAR } \\
\text { Up: miR-200b, miR- } \\
\text { 200c, let-7b, let-7c, let- } \\
\text { 7d, let-7e, miR-663, } \\
\text { miR-146a, miR-374b } \\
\text { Down: miR-34c, miR- } \\
\text { 376a, miR-196a, miR- } \\
\text { 320, miR-654, } \\
\text { miR-34c, miR-196 }\end{array}$ \\
\hline Hesperidin & Citrus & Cancer & DNMTi & In vitro & \\
\hline Isoliquiritigenin & Liquorice & Cancer & SIRTactivator & $\begin{array}{l}\text { In vitro / in vivo } \\
\text { Drosophila }\end{array}$ & \\
\hline $\begin{array}{l}\text { Isothiocyanate } \\
\text { (6-Methylsulfinyl- } \\
\text { hexylisothio- } \\
\text { cyanate) }\end{array}$ & $\begin{array}{l}\text { Broccoli, } \\
\text { Japanese } \\
\text { horseradish } \\
\text { (Wasabi) }\end{array}$ & $\begin{array}{l}\text { Anti-platelet effects } \\
\text { Cancer }\end{array}$ & HDACi & In vitro & P21, GSTP1 \\
\hline Kaempferol & $\begin{array}{l}\text { Apples, nuts, } \\
\text { tea, onions }\end{array}$ & Cancer & SIRTa & & \\
\hline Luteolin & Parsley, celery & Cancer & $\begin{array}{l}\text { DNMTi } \\
\text { SIRTactivator }\end{array}$ & $\begin{array}{l}\text { In vitro / In vivo } \\
\text { Drosophila }\end{array}$ & \\
\hline Lycopene & $\begin{array}{l}\text { Tomatoes, } \\
\text { Watermelon } \\
\text { Apricots } \\
\text { Pink guava } \\
\text { Grapefruit, } \\
\text { Rosehip }\end{array}$ & $\begin{array}{l}\text { Cancer: Breast, } \\
\text { Colon }\end{array}$ & DNMTi & In vitro & GSTP1, RAR $\beta$, HIN1 \\
\hline MCP30 & $\begin{array}{l}\text { Bitter melon } \\
\text { seeds } \\
\text { (Momordica } \\
\text { charantia) }\end{array}$ & Cancer & $\mathrm{HDACi}$ & In vitro & \\
\hline Myricetin & Berries & Cancer & DNMTi & In vitro & \\
\hline
\end{tabular}




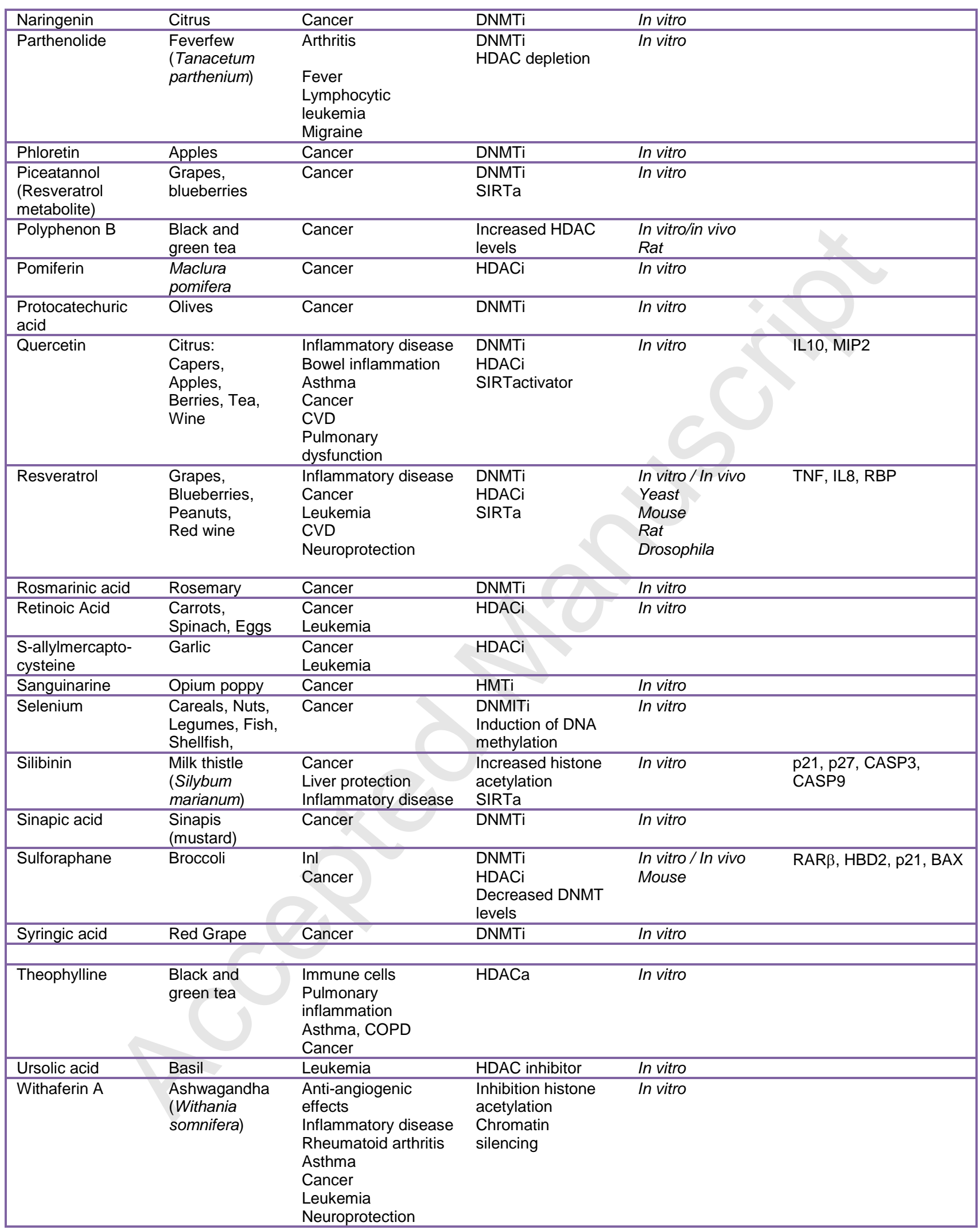




\section{References}

[1] Boffetta P, Couto E, Wichmann J, Ferrari P, Trichopoulos D, Bueno-de-Mesquita HB, et al. Fruit and vegetable intake and overall cancer risk in the European Prospective Investigation into Cancer and Nutrition (EPIC). Journal of the National Cancer Institute 2010;102:529-37.

[2] Bingham S, Riboli E. Diet and cancer--the European Prospective Investigation into Cancer and Nutrition. Nature reviews 2004;4:206-15.

[3] Anand P, Kunnumakkara AB, Sundaram C, Harikumar KB, Tharakan ST, Lai OS, et al. Cancer is a preventable disease that requires major lifestyle changes. PharmRes 2008;25:2097-116.

[4] Manolio TA, Collins FS, Cox NJ, Goldstein DB, Hindorff LA, Hunter DJ, et al. Finding the missing heritability of complex diseases. Nature 2009;461:747-53.

[5] Maher B. Personal genomes: The case of the missing heritability. Nature 2008;456:1821.

[6] Fraga MF, Ballestar E, Paz MF, Ropero S, Setien F, Ballestar ML, et al. Epigenetic differences arise during the lifetime of monozygotic twins. Proc Natl Acad Sci U S A 2005;102:10604-9.

[7] Fraga MF, Esteller M. Epigenetics and aging: the targets and the marks. Trends Genet 2007;23:413-8.

[8] Christensen BC, Houseman EA, Marsit CJ, Zheng S, Wrensch MR, Wiemels JL, et al. Aging and environmental exposures alter tissue-specific DNA methylation dependent upon CpG island context. PLoS genetics 2009;5:e1000602.

[9] Lee BM, Mahadevan LC. Stability of histone modifications across mammalian genomes: implications for 'epigenetic' marking. J Cell Biochem 2009;108:22-34.

[10] Vanden Berghe W, Ndlovu MN, Hoya-Arias R, Dijsselbloem N, Gerlo S, Haegeman G. Keeping up NF-kappaB appearances: epigenetic control of immunity or inflammation-triggered epigenetics. Biochem Pharmacol 2006;72:1114-31.

[11] Chi P, Allis CD, Wang GG. Covalent histone modifications--miswritten, misinterpreted and mis-erased in human cancers. Nature reviews 2010;10:457-69.

[12] Guil S, Esteller M. DNA methylomes, histone codes and miRNAs: tying it all together. Int J Biochem Cell Biol 2009;41:87-95.

[13] Davalos V, Esteller M. MicroRNAs and cancer epigenetics: a macrorevolution. Curr Opin Oncol 2010;22:35-45.

[14] Plomin R, Owen MJ, McGuffin P. The genetic basis of complex human behaviors. Science 1994;264:1733-9.

[15] Messina M, Hilakivi-Clarke L. Early intake appears to be the key to the proposed protective effects of soy intake against breast cancer. Nutr Cancer 2009;61:792-8.

[16] Shu XO, Zheng Y, Cai H, Gu K, Chen Z, Zheng W, et al. Soy food intake and breast cancer survival. JAMA 2009;302:2437-43.

[17] Tennant DA, Duran RV, Gottlieb E. Targeting metabolic transformation for cancer therapy. Nature reviews 2010;10:267-77.

[18] Lujambio A, Calin GA, Villanueva A, Ropero S, Sanchez-Cespedes M, Blanco D, et al. A microRNA DNA methylation signature for human cancer metastasis. Proc Natl Acad Sci U S A 2008;105:13556-61.

[19] Lujambio A, Esteller M. CpG island hypermethylation of tumor suppressor microRNAs in human cancer. Cell Cycle 2007;6:1455-9.

[20] Esteller M. Cancer epigenomics: DNA methylomes and histone-modification maps. Nat Rev Genet 2007;8:286-98. 
[21] Esteller M. Epigenetics in cancer. N Engl J Med 2008;358:1148-59.

[22] Backdahl L, Bushell A, Beck S. Inflammatory signaling as mediator of epigenetic modulation in tissue-specific chronic inflammation. Int $\mathrm{J}$ Biochem Cell Biol 2009;41:176-84.

[23] Mulero-Navarro S, Esteller M. Chromatin remodeling factor CHD5 is silenced by promoter CpG island hypermethylation in human cancer. Epigenetics 2008;3:210-5.

[24] Herceg Z. Epigenetics and cancer: towards an evaluation of the impact of environmental and dietary factors. Mutagenesis 2007;22:91-103.

[25] Miller RL, Ho SM. Environmental epigenetics and asthma: current concepts and call for studies. Am J Respir Crit Care Med 2008;177:567-73.

[26] Villeneuve LM, Natarajan R. The Role of Epigenetics in the Pathology of Diabetic Complications. Am J Physiol Renal Physiol 2010.

[27] Schwartz DA. Epigenetics and environmental lung disease. Proc Am Thorac Soc 2010;7:123-5.

[28] Gluckman PD, Hanson MA, Cooper C, Thornburg KL. Effect of in utero and early-life conditions on adult health and disease. N Engl J Med 2008;359:61-73.

[29] Godfrey KM, Gluckman PD, Hanson MA. Developmental origins of metabolic disease: life course and intergenerational perspectives. Trends Endocrinol Metab 2010;21:199-205.

[30] Moving AHEAD with an international human epigenome project. Nature 2008;454:711-5.

[31] Altucci L, Stunnenberg HG. Time for epigenetics. Int J Biochem Cell Biol 2009;41:23.

[32] Burdge GC, Lillycrop KA. Nutrition, Epigenetics, and Developmental Plasticity: Implications for Understanding Human Diseas. Annual Review of Nutrition 2010.

[33] Delage B, Dashwood RH. Dietary manipulation of histone structure and function. Annu Rev Nutr 2008;28:347-66.

[34] Link A, Balaguer F, Goel A. Cancer chemoprevention by dietary polyphenols: Promising role for epigenetics. Biochem Pharmacol 2010.

[35] Folmer F, Orlikova B, Schnekenburger M, Dicato M, Diederich M. Naturally occurring regulators of histone acetylation/deacetylation. Current Nutrition \& Food Science 2010;6:78-99.

[36] Hauser AT, Jung M. Targeting epigenetic mechanisms: potential of natural products in cancer chemoprevention. Planta Medica 2008;74:1593-601.

[37] Kontogiorgis C, Bompou E, Ntella M, Vanden Berghe W. Natural Products from Mediterranean Diet: From Anti-Inflammatory Agents to Dietary Epigenetic Modulators. Anti-Inflammatory \& Anti-Allergy Agents in Medicinal Chemistry 2010;6:101-24.

[38] Kirk H, Cefalu WT, Ribnicky D, Liu Z, Eilertsen KJ. Botanicals as epigenetic modulators for mechanisms contributing to development of metabolic syndrome. Metabolism: Clinical and Experimental 2008;57:S16-23.

[39] Fang M, Chen D, Yang CS. Dietary polyphenols may affect DNA methylation. The Journal of nutrition 2007;137:223S-8S.

[40] Suzuki T, Miyata N. Epigenetic control using natural products and synthetic molecules. Curr Med Chem 2006;13:935-58.

[41] Arasaradnam RP, Commane DM, Bradburn D, Mathers JC. A review of dietary factors and its influence on DNA methylation in colorectal carcinogenesis. Epigenetics 2008;3:193-8.

[42] Berger SL, Kouzarides T, Shiekhattar R, Shilatifard A. An operational definition of epigenetics. Genes Dev 2009;23:781-3. 
[43] Perissi V, Jepsen K, Glass CK, Rosenfeld MG. Deconstructing repression: evolving models of co-repressor action. Nat Rev Genet 2010;11:109-23.

[44] Vire E, Brenner C, Deplus R, Blanchon L, Fraga M, Didelot C, et al. The Polycomb group protein EZH2 directly controls DNA methylation. Nature 2006;439:871-4.

[45] Brenner C, Deplus R, Didelot C, Loriot A, Vire E, De Smet C, et al. Myc represses transcription through recruitment of DNA methyltransferase corepressor. EMBO J 2005;24:336-46.

[46] Hervouet E, Vallette FM, Cartron PF. Dnmt3/transcription factor interactions as crucial players in targeted DNA methylation. Epigenetics 2009;4:487-99.

[47] Seet BT, Dikic I, Zhou MM, Pawson T. Reading protein modifications with interaction domains. Nat Rev Mol Cell Biol 2006;7:473-83.

[48] Fischle W. Talk is cheap--cross-talk in establishment, maintenance, and readout of chromatin modifications. Genes and Development 2008;22:3375-82.

[49] Schreiber SL, Bernstein BE. Signaling network model of chromatin. Cell 2002;111:771-8.

[50] Bird A. DNA methylation patterns and epigenetic memory. Genes Dev 2002;16:6-21.

[51] Jones PA, Liang G. Rethinking how DNA methylation patterns are maintained. Nat Rev Genet 2009;10:805-11.

[52] Law JA, Jacobsen SE. Establishing, maintaining and modifying DNA methylation patterns in plants and animals. Nat Rev Genet 2010;11:204-20.

[53] Lees-Murdock DJ, Walsh CP. DNA methylation reprogramming in the germ line. Advances in Experimental Medicine and Biology 2008;626:1-15.

[54] Robertson KD. DNA methylation and human disease. Nature Reviews Genetics 2005;6:597-610.

[55] Miranda TB, Jones PA. DNA methylation: the nuts and bolts of repression. Journal of Cellular Physiology 2007;213:384-90.

[56] Scarano MI, Strazzullo M, Matarazzo MR, D'Esposito M. DNA methylation 40 years later: Its role in human health and disease. Journal of Cellular Physiology 2005;204:21-35.

[57] Lande-Diner L, Cedar H. Silence of the genes--mechanisms of long-term repression. Nature Reviews Genetics 2005;6:648-54.

[58] Vaissiere T, Sawan C, Herceg Z. Epigenetic interplay between histone modifications and DNA methylation in gene silencing. Mutation Research 2008;659:40-8.

[59] Chodavarapu RK, Feng S, Bernatavichute YV, Chen PY, Stroud H, Yu Y, et al. Relationship between nucleosome positioning and DNA methylation. Nature 2010;466:388-92.

[60] Cosgrove MS, Wolberger C. How does the histone code work? Biochemistry and Cell Biology 2005;83:468-76.

[61] Jenuwein T, Allis CD. Translating the histone code. Science 2001;293:1074-80.

[62] Margueron R, Trojer P, Reinberg D. The key to development: interpreting the histone code? Curr Opin Genet Dev 2005;15:163-76.

[63] Robertson AG, Bilenky M, Tam A, Zhao Y, Zeng T, Thiessen N, et al. Genome-wide relationship between histone $\mathrm{H} 3$ lysine 4 mono- and tri-methylation and transcription factor binding. Genome Research 2008;18:1906-17.

[64] Jones RS. Epigenetics: reversing the 'irreversible'. Nature 2007;450:357-9.

[65] Pons D, de Vries FR, van den Elsen PJ, Heijmans BT, Quax PH, Jukema JW. Epigenetic histone acetylation modifiers in vascular remodelling: new targets for therapy in cardiovascular disease. European Heart Journal 2009;30:266-77. 
[66] Bertram C, Khan O, Ohri S, Phillips DI, Matthews SG, Hanson MA. Transgenerational effects of prenatal nutrient restriction on cardiovascular and hypothalamic-pituitary-adrenal function. Journal of Physiology 2008;586:2217-29.

[67] Kim M, Long TI, Arakawa K, Wang R, Yu MC, Laird PW. DNA methylation as a biomarker for cardiovascular disease risk. PLoS One 5:e9692.

[68] Wierda RJ, Geutskens SB, Jukema JW, Quax PH, van den Elsen PJ. Epigenetics in atherosclerosis and inflammation. J Cell Mol Med 2010.

[69] Perissi V, Rosenfeld MG. Controlling nuclear receptors: the circular logic of cofactor cycles. Nat Rev Mol Cell Biol 2005;6:542-54.

[70] Nunez E, Fu XD, Rosenfeld MG. Nuclear organization in the 3D space of the nucleus - cause or consequence? Curr Opin Genet Dev 2009;19:424-36.

[71] Nolis IK, McKay DJ, Mantouvalou E, Lomvardas S, Merika M, Thanos D. Transcription factors mediate long-range enhancer-promoter interactions. Proc Natl Acad Sci U S A 2009;106:20222-7.

[72] Fujioka M, Wu X, Jaynes JB. A chromatin insulator mediates transgene homing and very long-range enhancer-promoter communication. Development 2009;136:3077-87.

[73] Metivier R, Reid G, Gannon F. Transcription in four dimensions: nuclear receptordirected initiation of gene expression. EMBO Rep 2006;7:161-7.

[74] Lieberman-Aiden E, van Berkum NL, Williams L, Imakaev M, Ragoczy T, Telling A, et al. Comprehensive mapping of long-range interactions reveals folding principles of the human genome. Science 2009;326:289-93.

[75] Taft RJ, Pang KC, Mercer TR, Dinger M, Mattick JS. Noncoding RNAs: regulators of disease. J Pathol 2009;220:126-39.

[76] Taft RJ, Glazov EA, Cloonan N, Simons C, Stephen S, Faulkner GJ, et al. Tiny RNAs associated with transcription start sites in animals. Nat Genet 2009;41:572-8.

[77] Mattick JS, Taft RJ, Faulkner GJ. A global view of genomic information - moving beyond the gene and the master regulator. Trends Genet 2009.

[78] Mattick JS, Amaral PP, Dinger ME, Mercer TR, Mehler MF. RNA regulation of epigenetic processes. Bioessays 2009;31:51-9.

[79] Tsai MC, Manor O, Wan Y, Mosammaparast N, Wang JK, Lan F, et al. Long Noncoding RNA as Modular Scaffold of Histone Modification Complexes. Science 2010.

[80] Gupta RA, Shah N, Wang KC, Kim J, Horlings HM, Wong DJ, et al. Long noncoding RNA HOTAIR reprograms chromatin state to promote cancer metastasis. Nature 2010;464:1071-6.

[81] De Santa F, Barozzi I, Mietton F, Ghisletti S, Polletti S, Tusi BK, et al. A large fraction of extragenic RNA pol II transcription sites overlap enhancers. PLoS Biology 2010;8:e1000384.

[82] Lujambio A, Esteller M. How epigenetics can explain human metastasis: a new role for microRNAs. Cell Cycle 2009;8:377-82.

[83] Mahfouz MM. RNA-directed DNA methylation: Mechanisms and functions. Plant Signal Behav 2010;5.

[84] Medzhitov R, Horng T. Transcriptional control of the inflammatory response. Nat Rev Immunol 2009;9:692-703.

[85] Pasparakis M. Regulation of tissue homeostasis by NF-kappaB signaling: implications for inflammatory diseases. Nat Rev Immunol 2009;9:778-88.

[86] Medzhitov R. Origin and physiological roles of inflammation. Nature 2008;454:42835 . 
[87] Cobb BS, Nesterova TB, Thompson E, Hertweck A, O'Connor E, Godwin J, et al. T cell lineage choice and differentiation in the absence of the RNase III enzyme Dicer. J Exp Med 2005;201:1367-73.

[88] Palstra RJ, Tolhuis B, Splinter E, Nijmeijer R, Grosveld F, de Laat W. The beta-globin nuclear compartment in development and erythroid differentiation. Nat Genet 2003;35:190-4.

[89] Wilson CB, Rowell E, Sekimata M. Epigenetic control of T-helper-cell differentiation. Nature Reviews Immunology 2009;9:91-105.

[90] Lambrecht BN, Hammad H. Taking our breath away: dendritic cells in the pathogenesis of asthma. Nature Reviews Immunology 2003;3:994-1003.

[91] Hammad H, Lambrecht BN. Dendritic cells and epithelial cells: linking innate and adaptive immunity in asthma. Nature Reviews Immunology 2008;8:193-204.

[92] Messi M, Giacchetto I, Nagata K, Lanzavecchia A, Natoli G, Sallusto F. Memory and flexibility of cytokine gene expression as separable properties of human $\mathrm{T}(\mathrm{H}) 1$ and $\mathrm{T}(\mathrm{H}) 2$ lymphocytes. Nat Immunol 2003;4:78-86.

[93] Shaheen SO, Adcock IM. The developmental origins of asthma: does epigenetics hold the key? American Journal of Respiratory and Critical Care Medicine 2009;180:690-1.

[94] Adcock IM, Ford P, Ito K, Barnes PJ. Epigenetics and airways disease. Respiratory Research 2006;7:21.

[95] Lambrecht BN, Hammad H. Biology of lung dendritic cells at the origin of asthma. Immunity 2009;31:412-24.

[96] Hammad H, Chieppa M, Perros F, Willart MA, Germain RN, Lambrecht BN. House dust mite allergen induces asthma via Toll-like receptor 4 triggering of airway structural cells. Nature Medicine 2009;15:410-6.

[97] Grivennikov SI, Karin M. Inflammation and oncogenesis: a vicious connection. Curr Opin Genet Dev 2010;20:65-71.

[98] Balkwill F, Charles KA, Mantovani A. Smoldering and polarized inflammation in the initiation and promotion of malignant disease. Cancer Cell 2005;7:211-7.

[99] Balkwill F, Mantovani A. Cancer and inflammation: implications for pharmacology and therapeutics. Clin Pharmacol Ther 2010;87:401-6.

[100] Aggarwal BB, Gehlot P. Inflammation and cancer: how friendly is the relationship for cancer patients? Curr Opin Pharmacol 2009;9:351-69.

[101] Solinas G, Karin M. JNK1 and IKK\{beta\}: molecular links between obesity and metabolic dysfunction. FASEB J 2010:in press.

[102] Park EJ, Lee JH, Yu GY, He G, Ali SR, Holzer RG, et al. Dietary and genetic obesity promote liver inflammation and tumorigenesis by enhancing IL-6 and TNF expression. Cell 2010;140:197-208.

[103] Olefsky JM. IKKepsilon: a bridge between obesity and inflammation. Cell 2009;138:834-6.

[104] Zhang X, Zhang G, Zhang H, Karin M, Bai H, Cai D. Hypothalamic IKKbeta/NFkappaB and ER stress link overnutrition to energy imbalance and obesity. Cell 2008;135:61-73.

[105] Hotamisligil GS. Endoplasmic reticulum stress and the inflammatory basis of metabolic disease. Cell 2010;140:900-17.

[106] Mandl J, Meszaros T, Banhegyi G, Hunyady L, Csala M. Endoplasmic reticulum: nutrient sensor in physiology and pathology. Trends Endocrinol Metab 2009;20:194201.

[107] Ghosh S, Hayden MS. New regulators of NF-kappaB in inflammation. Nat Rev Immunol 2008;8:837-48. 
[108] Karin M, Greten FR. NF-kappaB: linking inflammation and immunity to cancer development and progression. Nat Rev Immunol 2005;5:749-59.

[109] Chen LF, Greene WC. Shaping the nuclear action of NF-kappaB. Nat Rev Mol Cell Biol 2004;5:392-401.

[110] Chau TL, Gioia R, Gatot JS, Patrascu F, Carpentier I, Chapelle JP, et al. Are the IKKs and IKK-related kinases TBK1 and IKK-epsilon similarly activated? Trends Biochem Sci 2008;33:171-80.

[111] Chiang SH, Bazuine M, Lumeng CN, Geletka LM, Mowers J, White NM, et al. The protein kinase IKKepsilon regulates energy balance in obese mice. Cell 2009;138:96175.

[112] Perkins ND. Integrating cell-signaling pathways with NF-kappaB and IKK function. Nat Rev Mol Cell Biol 2007;8:49-62.

[113] Viatour P, Merville MP, Bours V, Chariot A. Phosphorylation of NF-kappaB and IkappaB proteins: implications in cancer and inflammation. Trends Biochem Sci 2005;30:43-52.

[114] Vermeulen L, Berghe WV, Beck IM, De Bosscher K, Haegeman G. The versatile role of MSKs in transcriptional regulation. Trends Biochem Sci 2009;34:311-8.

[115] Vermeulen L, De Wilde G, Van Damme P, Vanden Berghe W, Haegeman G. Transcriptional activation of the NF-kappaB p65 subunit by mitogen- and stressactivated protein kinase-1 (MSK1). EMBO J 2003;22:1313-24.

[116] Edmunds JW, Mahadevan LC. Cell signaling. Protein kinases seek close encounters with active genes. Science 2006;313:449-51.

[117] Nakanishi C, Toi M. Nuclear factor-kappaB inhibitors as sensitizers to anticancer drugs. Nature reviews 2005;5:297-309.

[118] Karin M. Nuclear factor-kappaB in cancer development and progression. Nature 2006;441:431-6.

[119] Arkan MC, Hevener AL, Greten FR, Maeda S, Li ZW, Long JM, et al. IKK-beta links inflammation to obesity-induced insulin resistance. Nat Med 2005;11:191-8.

[120] De Santa F, Totaro MG, Prosperini E, Notarbartolo S, Testa G, Natoli G. The histone H3 lysine-27 demethylase JMJD3 links inflammation to inhibition of polycombmediated gene silencing. Cell 2007;130:1083-94.

[121] Ghisletti S, Barozzi I, Mietton F, Polletti S, De Santa F, Venturini E, et al. Identification and characterization of enhancers controlling the inflammatory gene expression program in macrophages. Immunity 2010;32:317-28.

[122] Ghisletti S, Huang W, Ogawa S, Pascual G, Lin ME, Willson TM, et al. Parallel SUMOylation-dependent pathways mediate gene- and signal-specific transrepression by LXRs and PPARgamma. Mol Cell 2007;25:57-70.

[123] Smale ST. Seq-ing LPS-induced enhancers. Immunity 2010;32:296-8.

[124] Xu J, Watts JA, Pope SD, Gadue P, Kamps M, Plath K, et al. Transcriptional competence and the active marking of tissue-specific enhancers by defined transcription factors in embryonic and induced pluripotent stem cells. Genes Dev 2009;23:2824-38.

[125] Natoli G, Saccani S, Bosisio D, Marazzi I. Interactions of NF-kappaB with chromatin: the art of being at the right place at the right time. Nat Immunol 2005;6:439-45.

[126] Hager GL, McNally JG, Misteli T. Transcription dynamics. Mol Cell 2009;35:741-53.

[127] Sung MH, Salvatore L, De Lorenzi R, Indrawan A, Pasparakis M, Hager GL, et al. Sustained oscillations of NF-kappaB produce distinct genome scanning and gene expression profiles. PLoS One 2009;4:e7163. 
[128] Ramirez-Carrozzi VR, Braas D, Bhatt DM, Cheng CS, Hong C, Doty KR, et al. A unifying model for the selective regulation of inducible transcription by $\mathrm{CpG}$ islands and nucleosome remodeling. Cell 2009;138:114-28.

[129] O'Dea E, Hoffmann A. The regulatory logic of the NF-kappaB signaling system. Cold Spring Harb Perspect Biol 2010;2:a000216.

[130] Werner SL, Barken D, Hoffmann A. Stimulus specificity of gene expression programs determined by temporal control of IKK activity. Science 2005;309:1857-61.

[131] Hayden MS, Ghosh S. Shared principles in NF-kappaB signaling. Cell 2008;132:34462.

[132] Vanden Berghe W, De Bosscher K, Boone E, Plaisance S, Haegeman G. The nuclear factor-kappaB engages $\mathrm{CBP} / \mathrm{p} 300$ and histone acetyltransferase activity for transcriptional activation of the interleukin-6 gene promoter. $J$ Biol Chem 1999;274:32091-8.

[133] Ndlovu N, Van Lint C, Van Wesemael K, Callebert P, Chalbos D, Haegeman G, et al. Hyperactivated NF-\{kappa\}B and AP-1 transcription factors promote highly accessible chromatin and constitutive transcription across the interleukin-6 gene promoter in metastatic breast cancer cells. Mol Cell Biol 2009;29:5488-504.

[134] Eferl R, Wagner EF. AP-1: a double-edged sword in tumorigenesis. Nature reviews 2003;3:859-68.

[135] Rosenfeld MG, Lunyak VV, Glass CK. Sensors and signals: a coactivator/corepressor/epigenetic code for integrating signal-dependent programs of transcriptional response. Genes Dev 2006;20:1405-28.

[136] Dong J, Jimi E, Zhong H, Hayden MS, Ghosh S. Repression of gene expression by unphosphorylated NF-kappaB p65 through epigenetic mechanisms. Genes and Development 2008;22:1159-73.

[137] Natoli G, De Santa F. Shaping alternative NF-kappaB-dependent gene expression programs: new clues to specificity. Cell Death Differ 2006;13:693-6.

[138] Ford E, Thanos D. The transcriptional code of human IFN-beta gene expression. Biochimica et biophysica acta 2010.

[139] Ramirez-Carrozzi VR, Nazarian AA, Li CC, Gore SL, Sridharan R, Imbalzano AN, et al. Selective and antagonistic functions of SWI/SNF and Mi-2beta nucleosome remodeling complexes during an inflammatory response. Genes Dev 2006;20:282-96.

[140] Puto LA, Reed JC. Daxx represses RelB target promoters via DNA methyltransferase recruitment and DNA hypermethylation. Genes Dev 2008;22:998-1010.

[141] Maeda G, Chiba T, Kawashiri S, Satoh T, Imai K. Epigenetic inactivation of IkappaB Kinase-alpha in oral carcinomas and tumor progression. Clinical Cancer Research 2007;13:5041-7.

[142] O'Gorman A, Colleran A, Ryan A, Mann J, Egan LJ. Regulation of NF-\{kappa $\}$ B responses by epigenetic suppression of $\mathrm{I}\{$ kappa $\} \mathrm{B}\{$ alpha $\}$ expression in HCT116 intestinal epithelial cells. American Journal of Physiology Gastrointestinal and Liver Physiology 2010.

[143] Ashall L, Horton CA, Nelson DE, Paszek P, Harper CV, Sillitoe K, et al. Pulsatile stimulation determines timing and specificity of NF-kappaB-dependent transcription. Science 2009;324:242-6.

[144] El Gazzar M, Yoza BK, Chen X, Garcia BA, Young NL, McCall CE. Chromatinspecific remodeling by HMGB1 and linker histone $\mathrm{H} 1$ silences proinflammatory genes during endotoxin tolerance. Mol Cell Biol 2009;29:1959-71.

[145] El Gazzar M, Yoza BK, Hu JY, Cousart SL, McCall CE. Epigenetic silencing of tumor necrosis factor alpha during endotoxin tolerance. J Biol Chem 2007;282:2685764. 
[146] El-Osta A, Brasacchio D, Yao D, Pocai A, Jones PL, Roeder RG, et al. Transient high glucose causes persistent epigenetic changes and altered gene expression during subsequent normoglycemia. J Exp Med 2008;205:2409-17.

[147] Gerlo S, Haegeman G, Vanden Berghe W. Transcriptional regulation of autocrine IL-6 expression in multiple myeloma cells. Cell Signal 2008;20:1489-96.

[148] Boeke J, Regnard C, Cai W, Johansen J, Johansen KM, Becker PB, et al. Phosphorylation of SU(VAR)3-9 by the chromosomal kinase JIL-1. PLoS ONE 2010;5:e10042.

[149] Dijsselbloem N, Goriely S, Albarani V, Gerlo S, Francoz S, Marine JC, et al. A critical role for p53 in the control of NF-kappaB-dependent gene expression in TLR4stimulated dendritic cells exposed to Genistein. J Immunol 2007;178:5048-57.

[150] Vanden Berghe W, Dijsselbloem N, Vermeulen L, Ndlovu N, Boone E, Haegeman G. Attenuation of Mitogen- and Stress-Activated Protein Kinase-1-Driven Nuclear Factor-\{kappa\}B Gene Expression by Soy Isoflavones Does Not Require Estrogenic Activity. Cancer Res 2006;66:4852-62.

[151] Armenante F, Merola M, Furia A, Palmieri M. Repression of the IL-6 gene is associated with hypermethylation. Biochem Biophys Res Commun 1999;258:644-7.

[152] Dandrea M, Donadelli M, Costanzo C, Scarpa A, Palmieri M. MeCP2/H3meK9 are involved in IL-6 gene silencing in pancreatic adenocarcinoma cell lines. Nucleic Acids Res 2009;37:6681-90.

[153] Aaltonen T, Adelman J, Akimoto T, Albrow MG, Alvarez Gonzalez B, Amerio S, et al. Cross-section-constrained top-quark mass measurement from dilepton events at the Tevatron. Physical Review Letters 2008;100:062005.

[154] Liu S, Liu Z, Xie Z, Pang J, Yu J, Lehmann E, et al. Bortezomib induces DNA hypomethylation and silenced gene transcription by interfering with Sp1/NF-kappaBdependent DNA methyltransferase activity in acute myeloid leukemia. Blood 2008;111:2364-73.

[155] Santourlidis S, Warskulat U, Florl AR, Maas S, Pulte T, Fischer J, et al. Hypermethylation of the tumor necrosis factor receptor superfamily 6 (APT1, Fas, CD95/Apo-1) gene promoter at rel/nuclear factor kappaB sites in prostatic carcinoma. Mol Carcinog 2001;32:36-43.

[156] Liu X, Wang X, Zhang J, Lam EK, Shin VY, Cheng AS, et al. Warburg effect revisited: an epigenetic link between glycolysis and gastric carcinogenesis. Oncogene 2010;29:442-50.

[157] Yu H, Pardoll D, Jove R. STATs in cancer inflammation and immunity: a leading role for STAT3. Nature Reviews Cancer 2009;9:798-809.

[158] Iliopoulos D, Hirsch HA, Struhl K. An epigenetic switch involving NF-kappaB, Lin28, Let-7 MicroRNA, and IL6 links inflammation to cell transformation. Cell 2009;139:693-706.

[159] Wang H, Lathia JD, Wu Q, Wang J, Li Z, Heddleston JM, et al. Targeting interleukin 6 signaling suppresses glioma stem cell survival and tumor growth. Stem cells (Dayton, Ohio) 2009;27:2393-404.

[160] Min J, Zaslavsky A, Fedele G, McLaughlin SK, Reczek EE, De Raedt T, et al. An oncogene-tumor suppressor cascade drives metastatic prostate cancer by coordinately activating Ras and nuclear factor-kappaB. Nature Medicine 2010;16:286-94.

[161] Maeda S, Hikiba Y, Sakamoto K, Nakagawa H, Hirata Y, Hayakawa Y, et al. Ikappa B kinasebeta/nuclear factor-kappaB activation controls the development of liver metastasis by way of interleukin-6 expression. Hepatology 2009;50:1851-60. 
[162] Grivennikov S, Karin E, Terzic J, Mucida D, Yu GY, Vallabhapurapu S, et al. IL-6 and Stat 3 are required for survival of intestinal epithelial cells and development of colitis-associated cancer. Cancer Cell 2009;15:103-13.

[163] Naugler WE, Karin M. The wolf in sheep's clothing: the role of interleukin-6 in immunity, inflammation and cancer. Trends in Molecular Medicine 2008;14:109-19.

[164] Suttana W, Mankhetkorn S, Poompimon W, Palagani A, Zhokhov S, Gerlo S, et al. Differential chemosensitization of P-glycoprotein overexpressing K562/Adr cells by withaferin A and Siamois polyphenols. MolCancer 2010;9:99.

[165] Peng B, Hodge DR, Thomas SB, Cherry JM, Munroe DJ, Pompeia C, et al. Epigenetic silencing of the human nucleotide excision repair gene, hHR23B, in interleukin-6responsive multiple myeloma KAS-6/1 cells. J Biol Chem 2005;280:4182-7.

[166] Pompeia C, Hodge DR, Plass C, Wu YZ, Marquez VE, Kelley JA, et al. Microarray analysis of epigenetic silencing of gene expression in the KAS-6/1 multiple myeloma cell line. Cancer Res 2004;64:3465-73.

[167] Hodge DR, Peng B, Pompeia C, Thomas S, Cho E, Clausen PA, et al. Epigenetic Silencing of Manganese Superoxide Dismutase (SOD-2) in KAS 6/1 Human Multiple Myeloma Cells Increases Cell Proliferation. Cancer Biol Ther 2005;4.

[168] Hodge DR, Cho E, Copeland TD, Guszczynski T, Yang E, Seth AK, et al. IL-6 enhances the nuclear translocation of DNA cytosine-5-methyltransferase 1 (DNMT1) via phosphorylation of the nuclear localization sequence by the AKT kinase. Cancer Genomics Proteomics 2007;4:387-98.

[169] Braconi C, Huang N, Patel T. MicroRNA-dependent regulation of DNA methyltransferase- 1 and tumor suppressor gene expression by interleukin- 6 in human malignant cholangiocytes. Hepatology 2010;51:881-90.

[170] Meng F, Wehbe-Janek H, Henson R, Smith H, Patel T. Epigenetic regulation of microRNA-370 by interleukin- 6 in malignant human cholangiocytes. Oncogene 2008;27:378-86.

[171] Croonquist PA, Van Ness B. The polycomb group protein enhancer of zeste homolog 2 (EZH 2) is an oncogene that influences myeloma cell growth and the mutant ras phenotype. Oncogene 2005;24:6269-80.

[172] Mathews LA, Crea F, Farrar WL. Epigenetic gene regulation in stem cells and correlation to cancer. Differentiation 2009;78:1-17.

[173] Kawasaki BT, Hurt EM, Mistree T, Farrar WL. Targeting cancer stem cells with phytochemicals. Mol Interv 2008;8:174-84.

[174] Hodge DR, Peng B, Cherry JC, Hurt EM, Fox SD, Kelley JA, et al. Interleukin 6 supports the maintenance of p53 tumor suppressor gene promoter methylation. Cancer Res 2005;65:4673-82.

[175] Hodge DR, Xiao W, Clausen PA, Heidecker G, Szyf M, Farrar WL. Interleukin-6 regulation of the human DNA methyltransferase (HDNMT) gene in human erythroleukemia cells. J Biol Chem 2001;276:39508-11.

[176] Kim KC, Friso S, Choi SW. DNA methylation, an epigenetic mechanism connecting folate to healthy embryonic development and aging. J Nutr Biochem 2009;20:917-26.

[177] Sharma SV, Lee DY, Li B, Quinlan MP, Takahashi F, Maheswaran S, et al. A chromatin-mediated reversible drug-tolerant state in cancer cell subpopulations. Cell 2010;141:69-80.

[178] Galkina E, Ley K. Vascular adhesion molecules in atherosclerosis. Arteriosclerosis, Thrombosis, and Vascular Biology 2007;27:2292-301.

[179] Galkina E, Ley K. Immune and inflammatory mechanisms of atherosclerosis (*). Annual Review of Immunology 2009;27:165-97. 
[180] Lund G, Zaina S. Atherosclerosis, lipids, inflammation and epigenetics. Current Opinion in Lipidology 2007;18:699-701.

[181] Lund G, Zaina S. Atherosclerosis risk factors can impose aberrant DNA methylation patterns: a tale of traffic and homocysteine. Current Opinion in Lipidology 2009;20:448-9.

[182] Lund G, Zaina S. Epigenetics, transgenerational effects and risk factors for atherosclerosis. Current Opinion in Lipidology 2009;20:150-1.

[183] Turunen MP, Aavik E, Yla-Herttuala S. Epigenetics and atherosclerosis. Biochimica et biophysica acta 2009;1790:886-91.

[184] Yu W, Fu YC, Chen CJ, Wang X, Wang W. SIRT1: a novel target to prevent atherosclerosis. J Cell Biochem 2009;108:10-3.

[185] Zaina S, Lindholm MW, Lund G. Nutrition and aberrant DNA methylation patterns in atherosclerosis: more than just hyperhomocysteinemia? Journal of Nutrition 2005;135:5-8.

[186] Franco R, Schoneveld O, Georgakilas AG, Panayiotidis MI. Oxidative stress, DNA methylation and carcinogenesis. Cancer Lett 2008;266:6-11.

[187] Forneris F, Binda C, Battaglioli E, Mattevi A. LSD1: oxidative chemistry for multifaceted functions in chromatin regulation. Trends in Biochemical Sciences 2008;33:181-9.

[188] Illi B, Colussi C, Grasselli A, Farsetti A, Capogrossi MC, Gaetano C. NO sparks off chromatin: tales of a multifaceted epigenetic regulator. Pharmacol Ther 2009;123:34452.

[189] Brewer GJ. Epigenetic oxidative redox shift (EORS) theory of aging unifies the free radical and insulin signaling theories. Experimental Gerontology 2010;45:173-9.

[190] Carta S, Castellani P, Delfino L, Tassi S, Vene R, Rubartelli A. DAMPs and inflammatory processes: the role of redox in the different outcomes. J Leukoc Biol 2009;86:549-55.

[191] Wen H, Schaller MA, Dou Y, Hogaboam CM, Kunkel SL. Dendritic cells at the interface of innate and acquired immunity: the role for epigenetic changes. Journal of Leukocyte Biology 2008;83:439-46.

[192] Ng SS, Yue WW, Oppermann U, Klose RJ. Dynamic protein methylation in chromatin biology. Cellular and Molecular Life Sciences 2009;66:407-22.

[193] Klose RJ, Zhang Y. Regulation of histone methylation by demethylimination and demethylation. Nature Reviews Molecular Cell Biology 2007;8:307-18.

[194] Jhunjhunwala S, van Zelm MC, Peak MM, Murre C. Chromatin architecture and the generation of antigen receptor diversity. Cell 2009;138:435-48.

[195] Parra M. Epigenetic events during B lymphocyte development. Epigenetics 2009;4:462-8.

[196] Martino DJ, Prescott SL. Silent mysteries: epigenetic paradigms could hold the key to conquering the epidemic of allergy and immune disease. Allergy 2010;65:7-15.

[197] Prescott SL, Clifton V. Asthma and pregnancy: emerging evidence of epigenetic interactions in utero. Current Opinion in Allergy and Clinical Immunology 2009;9:417-26.

[198] Karouzakis E, Gay RE, Gay S, Neidhart M. Epigenetic control in rheumatoid arthritis synovial fibroblasts. Nature Reviews Rheumatology 2009;5:266-72.

[199] Patel DR, Richardson BC. Epigenetic mechanisms in lupus. Current Opinion in Rheumatology 2010.

[200] Rodriguez-Canales J, Hanson JC, Tangrea MA, Erickson HS, Albert PS, Wallis BS, et al. Identification of a unique epigenetic sub-microenvironment in prostate cancer. Journal of Pathology 2007;211:410-9. 
[201] Hewagama A, Richardson B. The genetics and epigenetics of autoimmune diseases. Journal of Autoimmunity 2009;33:3-11.

[202] Barnett M, Bermingham E, McNabb W, Bassett S, Armstrong K, Rounce J, et al. Investigating micronutrients and epigenetic mechanisms in relation to inflammatory bowel disease. Mutation Research 2010.

[203] Zhang QJ, Wang Z, Chen HZ, Zhou S, Zheng W, Liu G, et al. Endothelium-specific overexpression of class III deacetylase SIRT1 decreases atherosclerosis in apolipoprotein E-deficient mice. Cardiovasc Res 2008;80:191-9.

[204] Cooney CA. Germ cells carry the epigenetic benefits of grandmother's diet. Proc Natl Acad Sci U S A 2006;103:17071-2.

[205] Weaver IC. Shaping adult phenotypes through early life environments. Birth Defects Research Part C, Embryo Today 2009;87:314-26.

[206] Aguilera O, Fernandez AF, Munoz A, Fraga MF. Epigenetics and environment: a complex relationship. J Appl Physiol 2010;109:243-51.

[207] Youngson NA, Whitelaw E. Transgenerational epigenetic effects. Annual Review of Genomics and Human Genetics 2008;9:233-57.

[208] Gallou-Kabani C, Vige A, Gross MS, Junien C. Nutri-epigenomics: lifelong remodelling of our epigenomes by nutritional and metabolic factors and beyond. Clin Chem Lab Med 2007;45:321-7.

[209] Anway MD, Cupp AS, Uzumcu M, Skinner MK. Epigenetic transgenerational actions of endocrine disruptors and male fertility. Science 2005;308:1466-9.

[210] Anway MD, Skinner MK. Epigenetic transgenerational actions of endocrine disruptors. Endocrinology 2006;147:S43-9.

[211] Jirtle RL, Skinner MK. Environmental epigenomics and disease susceptibility. Nat Rev Genet 2007;8:253-62.

[212] Barker DJ, Martyn CN. The maternal and fetal origins of cardiovascular disease. Journal of Epidemiology and Community Health 1992;46:8-11.

[213] Jackson AA, Burdge GC, Lillycrop KA. Diet, nutrition and modulation of genomic expression in fetal origins of adult disease. World Review of Nutrition and Dietetics 2010;101:56-72.

[214] Chmurzynska A. Fetal programming: link between early nutrition, DNA methylation, and complex diseases. Nutrition Reviews 2010;68:87-98.

[215] Kaminsky ZA, Tang T, Wang SC, Ptak C, Oh GH, Wong AH, et al. DNA methylation profiles in monozygotic and dizygotic twins. Nature Genetics 2009;41:240-5.

[216] Petronis A. Epigenetics and twins: three variations on the theme. Trends in Genetics 2006;22:347-50.

[217] Dolinoy DC, Weidman JR, Waterland RA, Jirtle RL. Maternal genistein alters coat color and protects Avy mouse offspring from obesity by modifying the fetal epigenome. Environ Health Perspect 2006;114:567-72.

[218] Dolinoy DC, Jirtle RL. Environmental epigenomics in human health and disease. Environ Mol Mutagen 2008;49:4-8.

[219] Waterland RA. Is epigenetics an important link between early life events and adult disease? Horm Res 2009;71 Suppl 1:13-6.

[220] Vandegehuchte MB, Lemiere F, Vanhaecke L, Vanden Berghe W, Janssen CR. Direct and transgenerational impact on Daphnia magna of chemicals with a known effect on DNA methylation. Comparative Biochemistry and Physiology Toxicology and Pharmacology 2010;151:278-85.

[221] Miller RL. Prenatal maternal diet affects asthma risk in offspring. J Clin Invest 2008;118:3265-8. 
[222] Gabor Miklos GL, Maleszka R. Epigenomic communication systems in humans and honey bees: From molecules to behavior. Horm Behav 2010.

[223] Kucharski R, Maleszka J, Foret S, Maleszka R. Nutritional control of reproductive status in honeybees via DNA methylation. Science 2008;319:1827-30.

[224] Maleszka R. Epigenetic integration of environmental and genomic signals in honey bees: the critical interplay of nutritional, brain and reproductive networks. Epigenetics 2008;3:188-92.

[225] Foret S, Kucharski R, Pittelkow Y, Lockett GA, Maleszka R. Epigenetic regulation of the honey bee transcriptome: unravelling the nature of methylated genes. BMC Genomics 2009; 10:472.

[226] Painter RC, Osmond C, Gluckman P, Hanson M, Phillips DI, Roseboom TJ. Transgenerational effects of prenatal exposure to the Dutch famine on neonatal adiposity and health in later life. BJOG 2008;115:1243-9.

[227] Lumey LH, Stein AD. Transgenerational effects of prenatal exposure to the Dutch famine. BJOG 2009;116:868; author reply

[228] Roseboom T, de Rooij S, Painter R. The Dutch famine and its long-term consequences for adult health. Early Human Development 2006;82:485-91.

[229] Whitelaw E. Epigenetics: sins of the fathers, and their fathers. European Journal of Human Genetics 2006;14:131-2.

[230] Kaati G, Bygren LO, Edvinsson S. Cardiovascular and diabetes mortality determined by nutrition during parents' and grandparents' slow growth period. European Journal of Human Genetics 2002;10:682-8.

[231] Hanson MA, Gluckman PD. Developmental processes and the induction of cardiovascular function: conceptual aspects. J Physiol 2005;565:27-34.

[232] Waldo SW, Li Y, Buono C, Zhao B, Billings EM, Chang J, et al. Heterogeneity of human macrophages in culture and in atherosclerotic plaques. American Journal of Pathology 2008;172:1112-26.

[233] Sharma P, Senthilkumar RD, Brahmachari V, Sundaramoorthy E, Mahajan A, Sharma A, et al. Mining literature for a comprehensive pathway analysis: a case study for retrieval of homocysteine related genes for genetic and epigenetic studies. Lipids Health Dis 2006;5:1.

[234] Chen NC, Yang F, Capecci LM, Gu Z, Schafer AI, Durante W, et al. Regulation of homocysteine metabolism and methylation in human and mouse tissues. FASEB Journal 2010.

[235] Jiang Y, Sun T, Xiong J, Cao J, Li G, Wang S. Hyperhomocysteinemia-mediated DNA hypomethylation and its potential epigenetic role in rats. Acta Biochim Biophys Sin (Shanghai) 2007;39:657-67.

[236] Kim JM, Hong K, Lee JH, Lee S, Chang N. Effect of folate deficiency on placental DNA methylation in hyperhomocysteinemic rats. J Nutr Biochem 2009;20:172-6.

[237] Bistulfi G, Vandette E, Matsui S, Smiraglia DJ. Mild folate deficiency induces genetic and epigenetic instability and phenotype changes in prostate cancer cells. BMCBiol 2010;8:6.

[238] Ghoshal K, Li X, Datta J, Bai S, Pogribny I, Pogribny M, et al. A folate- and methyldeficient diet alters the expression of DNA methyltransferases and methyl CpG binding proteins involved in epigenetic gene silencing in livers of F344 rats. The Journal of nutrition 2006;136:1522-7.

[239] Ulrich CM, Reed MC, Nijhout HF. Modeling folate, one-carbon metabolism, and DNA methylation. Nutr Rev 2008;66 Suppl 1:S27-30. 
[240] Pogribny IP, Tryndyak VP, Muskhelishvili L, Rusyn I, Ross SA. Methyl deficiency, alterations in global histone modifications, and carcinogenesis. The Journal of nutrition 2007;137:216S-22S.

[241] Manach C, Mazur A, Scalbert A. Polyphenols and prevention of cardiovascular diseases. Curr Opin Lipidol 2005;16:77-84.

[242] Fisher ND, Hollenberg NK. Aging and vascular responses to flavanol-rich cocoa. Journal of Hypertension 2006;24:1575-80.

[243] Sies H, Schewe T, Heiss C, Kelm M. Cocoa polyphenols and inflammatory mediators. American Journal of Clinical Nutrition 2005;81:304S-12S.

[244] Heiss C, Kleinbongard P, Dejam A, Perre S, Schroeter H, Sies H, et al. Acute consumption of flavanol-rich cocoa and the reversal of endothelial dysfunction in smokers. Journal of the American College of Cardiology 2005;46:1276-83.

[245] Baur JA, Sinclair DA. Therapeutic potential of resveratrol: the in vivo evidence. Nat Rev Drug Discov 2006;5:493-506.

[246] Bertelli AA, Das DK. Grapes, wines, resveratrol, and heart health. J Cardiovasc Pharmacol 2009;54:468-76.

[247] van Straten EM, Bloks VW, Huijkman NC, Baller JF, Meer H, Lutjohann D, et al. The liver X-receptor gene promoter is hypermethylated in a mouse model of prenatal protein restriction. American Journal of Physiology Regulatory, Integrative and Comparative Physiology 2010;298:R275-82.

[248] Burdge GC, Slater-Jefferies J, Torrens C, Phillips ES, Hanson MA, Lillycrop KA. Dietary protein restriction of pregnant rats in the F0 generation induces altered methylation of hepatic gene promoters in the adult male offspring in the F1 and F2 generations. Br J Nutr 2007;97:435-9.

[249] Lillycrop KA, Phillips ES, Jackson AA, Hanson MA, Burdge GC. Dietary protein restriction of pregnant rats induces and folic acid supplementation prevents epigenetic modification of hepatic gene expression in the offspring. The Journal of nutrition 2005;135:1382-6.

[250] Tateishi K, Okada Y, Kallin EM, Zhang Y. Role of Jhdm2a in regulating metabolic gene expression and obesity resistance. Nature 2009;458:757-61.

[251] Reddy MA, Villeneuve LM, Wang M, Lanting L, Natarajan R. Role of the lysinespecific demethylase 1 in the proinflammatory phenotype of vascular smooth muscle cells of diabetic mice. Circulation Research 2008;103:615-23.

[252] Brasacchio D, Okabe J, Tikellis C, Balcerczyk A, George P, Baker EK, et al. Hyperglycemia induces a dynamic cooperativity of histone methylase and demethylase enzymes associated with gene-activating epigenetic marks that coexist on the lysine tail. Diabetes 2009;58:1229-36.

[253] Attig L, Gabory A, Junien C. Nutritional developmental epigenomics: immediate and long-lasting effects. Proceedings of the Nutrition Society 2010;69:221-31.

[254] Gallou-Kabani C, Junien C. Nutritional epigenomics of metabolic syndrome: new perspective against the epidemic. Diabetes 2005;54:1899-906.

[255] Karemaker R, Karemaker JM, Kavelaars A, Tersteeg-Kamperman M, Baerts W, Veen $\mathrm{S}$, et al. Effects of neonatal dexamethasone treatment on the cardiovascular stress response of children at school age. Pediatrics 2008;122:978-87.

[256] Barres R, Osler ME, Yan J, Rune A, Fritz T, Caidahl K, et al. Non-CpG methylation of the PGC-1alpha promoter through DNMT3B controls mitochondrial density. Cell Metabolism 2009;10:189-98.

[257] Plagemann A, Roepke K, Harder T, Brunn M, Harder A, Wittrock-Staar M, et al. Epigenetic malprogramming of the insulin receptor promoter due to developmental overfeeding. Journal of Perinatal Medicine 2010. 
[258] Plagemann A, Harder T, Brunn M, Harder A, Roepke K, Wittrock-Staar M, et al. Hypothalamic proopiomelanocortin promoter methylation becomes altered by early overfeeding: an epigenetic model of obesity and the metabolic syndrome. Journal of Physiology 2009;587:4963-76.

[259] Burdge GC, Lillycrop KA, Jackson AA. Nutrition in early life, and risk of cancer and metabolic disease: alternative endings in an epigenetic tale? British Journal of Nutrition 2009;101:619-30.

[260] De Assis S, Hilakivi-Clarke L. Timing of dietary estrogenic exposures and breast cancer risk. Ann N Y Acad Sci 2006;1089:14-35.

[261] Guerrero-Bosagna CM, Sabat P, Valdovinos FS, Valladares LE, Clark SJ. Epigenetic and phenotypic changes result from a continuous pre and post natal dietary exposure to phytoestrogens in an experimental population of mice. BMC Physiol 2008;8:17.

[262] Hunter P. We are what we eat. The link between diet, evolution and non-genetic inheritance. EMBO Rep 2008;9:413-5.

[263] Waterland RA, Travisano M, Tahiliani KG, Rached MT, Mirza S. Methyl donor supplementation prevents transgenerational amplification of obesity. Int J Obes (Lond) 2008;32:1373-9.

[264] Waterland RA, Jirtle RL. Early nutrition, epigenetic changes at transposons and imprinted genes, and enhanced susceptibility to adult chronic diseases. Nutrition 2004;20:63-8.

[265] Surani MA, Ancelin K, Hajkova P, Lange UC, Payer B, Western P, et al. Mechanism of mouse germ cell specification: a genetic program regulating epigenetic reprogramming. Cold Spring Harbor Symposia on Quantitative Biology 2004;69:1-9.

[266] Hajkova P, Ancelin K, Waldmann T, Lacoste N, Lange UC, Cesari F, et al. Chromatin dynamics during epigenetic reprogramming in the mouse germ line. Nature 2008;452:877-81.

[267] Chong S, Youngson NA, Whitelaw E. Heritable germline epimutation is not the same as transgenerational epigenetic inheritance. Nature Genetics 2007;39:574-5; author reply 5-6.

[268] Blewitt ME, Vickaryous NK, Paldi A, Koseki H, Whitelaw E. Dynamic Reprogramming of DNA Methylation at an Epigenetically Sensitive Allele in Mice. PLoS genetics 2006;2:e49.

[269] Bracken AP, Helin K. Polycomb group proteins: navigators of lineage pathways led astray in cancer. Nature reviews 2009;9:773-84.

[270] Li Y, Kong D, Wang Z, Sarkar FH. Regulation of microRNAs by Natural Agents: An Emerging Field in Chemoprevention and Chemotherapy Research. Pharmaceutical Research 2010;27:1027-41.

[271] Ruden DM, Xiao L, Garfinkel MD, Lu X. Hsp90 and environmental impacts on epigenetic states: a model for the trans-generational effects of diethylstibesterol on uterine development and cancer. Hum Mol Genet 2005;14 Spec No 1:R149-55.

[272] Sollars V, Lu X, Xiao L, Wang X, Garfinkel MD, Ruden DM. Evidence for an epigenetic mechanism by which $\mathrm{Hsp} 90$ acts as a capacitor for morphological evolution. Nature Genetics 2003;33:70-4.

[273] Ruden DM, De Luca M, Garfinkel MD, Bynum KL, Lu X. Drosophila nutrigenomics can provide clues to human gene-nutrient interactions. Annu Rev Nutr 2005;25:499522.

[274] Dijsselbloem N, Vanden Berghe W, De Naeyer A, Haegeman G. Soy isoflavone phyto-pharmaceuticals in interleukin- 6 affections: multi-purpose nutraceuticals at the crossroad of hormone replacement, anti-cancer and anti-inflammatory therapy. Biochem Pharmacol 2004;68:1171-85. 
[275] Surh YJ. Cancer chemoprevention with dietary phytochemicals. Nature reviews 2003;3:768-80.

[276] Blanpain C, Fuchs E. Epidermal homeostasis: a balancing act of stem cells in the skin. Nat Rev Mol Cell Biol 2009;10:207-17.

[277] Crea F, Mathews LA, Farrar WL, Hurt EM. Targeting prostate cancer stem cells. Anticancer Agents Med Chem 2009;9:1105-13.

[278] Shytle RD, Ehrhart J, Tan J, Vila J, Cole M, Sanberg CD, et al. Oxidative stress of neural, hematopoietic, and stem cells: protection by natural compounds. Rejuvenation Res 2007;10:173-8.

[279] Bickford PC, Tan J, Shytle RD, Sanberg CD, El-Badri N, Sanberg PR. Nutraceuticals synergistically promote proliferation of human stem cells. Stem Cells Dev 2006;15:118-23.

[280] Zhou J, Zhang H, Gu P, Bai J, Margolick JB, Zhang Y. NF-kappaB pathway inhibitors preferentially inhibit breast cancer stem-like cells. Breast Cancer Res Treat 2008;111:419-27.

[281] Aggarwal BB. Inflammation, a silent killer in cancer is not so silent! Curr Opin Pharmacol 2009;9:347-50.

[282] Vaquero A, Reinberg D. Calorie restriction and the exercise of chromatin. Genes Dev 2009;23:1849-69.

[283] Mai A, Cheng D, Bedford MT, Valente S, Nebbioso A, Perrone A, et al. Epigenetic multiple ligands: mixed histone/protein methyltransferase, acetyltransferase, and class III deacetylase (sirtuin) inhibitors. J Med Chem 2008;51:2279-90.

[284] Kuniyasu H. The Roles of Dietary PPARgamma Ligands for Metastasis in Colorectal Cancer. PPAR research 2008;2008:529720.

[285] Denison MS, Nagy SR. Activation of the aryl hydrocarbon receptor by structurally diverse exogenous and endogenous chemicals. Annual review of pharmacology and toxicology 2003;43:309-34.

[286] Darbre PD, Charles AK. Environmental oestrogens and breast cancer: evidence for combined involvement of dietary, household and cosmetic xenoestrogens. Anticancer Res 2010;30:815-27.

[287] Newbold RR, Padilla-Banks E, Jefferson WN. Environmental estrogens and obesity. Mol Cell Endocrinol 2009;304:84-9.

[288] Manach C, Donovan JL. Pharmacokinetics and metabolism of dietary flavonoids in humans. Free Radic Res 2004;38:771-85.

[289] Manach C, Williamson G, Morand C, Scalbert A, Remesy C. Bioavailability and bioefficacy of polyphenols in humans. I. Review of 97 bioavailability studies. Am J Clin Nutr 2005;81:230S-42S.

[290] Manach C, Scalbert A, Morand C, Remesy C, Jimenez L. Polyphenols: food sources and bioavailability. Am J Clin Nutr 2004;79:727-47.

[291] Williamson G, Manach C. Bioavailability and bioefficacy of polyphenols in humans. II. Review of 93 intervention studies. Am J Clin Nutr 2005;81:243S-55S.

[292] Zheng YG, Wu J, Chen Z, Goodman M. Chemical regulation of epigenetic modifications: opportunities for new cancer therapy. Med Res Rev 2008;28:645-87.

[293] Wigle TJ, Herold JM, Senisterra GA, Vedadi M, Kireev DB, Arrowsmith CH, et al. Screening for inhibitors of low-affinity epigenetic peptide-protein interactions: an AlphaScreen-based assay for antagonists of methyl-lysine binding proteins. J Biomol Screen 15:62-71.

[294] Altucci L, Minucci S. Epigenetic therapies in haematological malignancies: searching for true targets. Eur J Cancer 2009;45:1137-45. 
[295] Pacholec M, Bleasdale JE, Chrunyk B, Cunningham D, Flynn D, Garofalo RS, et al. SRT1720, SRT2183, SRT1460, and resveratrol are not direct activators of SIRT1. J Biol Chem 2010;285:8340-51.

[296] Ladurner AG. Chromatin places metabolism center stage. Cell 2009;138:18-20.

[297] Imai S, Guarente L. Ten years of NAD-dependent SIR2 family deacetylases: implications for metabolic diseases. Trends Pharmacol Sci 2010;31:212-20.

[298] Chiang EP, Wang YC, Chen WW, Tang FY. Effects of insulin and glucose on cellular metabolic fluxes in homocysteine transsulfuration, remethylation, $S$ adenosylmethionine synthesis, and global deoxyribonucleic acid methylation. Journal of Clinical Endocrinology and Metabolism 2009;94:1017-25.

[299] Lee DH, Jacobs DR, Jr., Porta M. Hypothesis: a unifying mechanism for nutrition and chemicals as lifelong modulators of DNA hypomethylation. Environ Health Perspect 2009;117:1799-802.

[300] Whittle JR, Powell MJ, Popov VM, Shirley LA, Wang C, Pestell RG. Sirtuins, nuclear hormone receptor acetylation and transcriptional regulation. Trends Endocrinol Metab 2007;18:356-64.

[301] Paul AT, Gohil VM, Bhutani KK. Modulating TNF-alpha signaling with natural products. Drug Discov Today 2006;11:725-32.

[302] Rios JL, Recio MC, Escandell JM, Andujar I. Inhibition of transcription factors by plant-derived compounds and their implications in inflammation and cancer. Curr Pharm Des 2009;15:1212-37.

[303] Deorukhkar A, Krishnan S, Sethi G, Aggarwal BB. Back to basics: how natural products can provide the basis for new therapeutics. Expert Opin Investig Drugs 2007;16:1753-73.

[304] Khanna D, Sethi G, Ahn KS, Pandey MK, Kunnumakkara AB, Sung B, et al. Natural products as a gold mine for arthritis treatment. Curr Opin Pharmacol 2007;7:344-51.

[305] Bremner P, Heinrich M. Natural products as targeted modulators of the nuclear factorkappaB pathway. J Pharm Pharmacol 2002;54:453-72.

[306] Karin M, Yamamoto Y, Wang QM. The IKK NF-kappa B system: a treasure trove for drug development. Nat Rev Drug Discov 2004;3:17-26.

[307] Biddie SC, John S, Hager GL. Genome-wide mechanisms of nuclear receptor action. Trends Endocrinol Metab 2010;21:3-9.

[308] Fiskus W, Wang Y, Sreekumar A, Buckley KM, Shi H, Jillella A, et al. Combined epigenetic therapy with the histone methyltransferase EZH2 inhibitor 3deazaneplanocin A and the histone deacetylase inhibitor panobinostat against human AML cells. Blood 2009;114:2733-43.

[309] Di Croce L, Raker VA, Corsaro M, Fazi F, Fanelli M, Faretta M, et al. Methyltransferase recruitment and DNA hypermethylation of target promoters by an oncogenic transcription factor. Science 2002;295:1079-82.

[310] Vanden Berghe W, Francesconi E, De Bosscher K, Resche-Rigon M, Haegeman G. Dissociated glucocorticoids with anti-inflammatory potential repress interleukin-6 gene expression by a nuclear factor-kappaB-dependent mechanism. Mol Pharmacol 1999;56:797-806.

[311] Vanden Berghe W, Plaisance S, Boone E, De Bosscher K, Schmitz ML, Fiers W, et al. p38 and extracellular signal-regulated kinase mitogen-activated protein kinase pathways are required for nuclear factor-kappaB p65 transactivation mediated by tumor necrosis factor. J Biol Chem 1998;273:3285-90.

[312] Kaileh M, Vanden Berghe W, Heyerick A, Horion J, Piette J, Libert C, et al. Withaferin a strongly elicits IkappaB kinase beta hyperphosphorylation concomitant with potent inhibition of its kinase activity. J Biol Chem 2007;282:4253-64. 


\section{Metabolic Stress ER Stress \\ Oxidative Stress}

Phylochemical Chemoprevention Caloric restriction Heallhy Aging
Mut.

SNP

\section{Chronic Inflammation Infection, UV, Cell damage Toxin, Endocrine disruptors Hormonal imbalance \\ SNP}

Histone code

Nutritional epigenomics

MIRNA

nCRNA

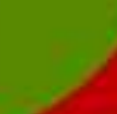

Nutritional

Deficiencies

Malnutrition

Overnutrition

Mut

SNP

Aging Lifestyle Disease CVD, diabetes, obesity Asthma/COPD, Cancer Neurodegeneration 


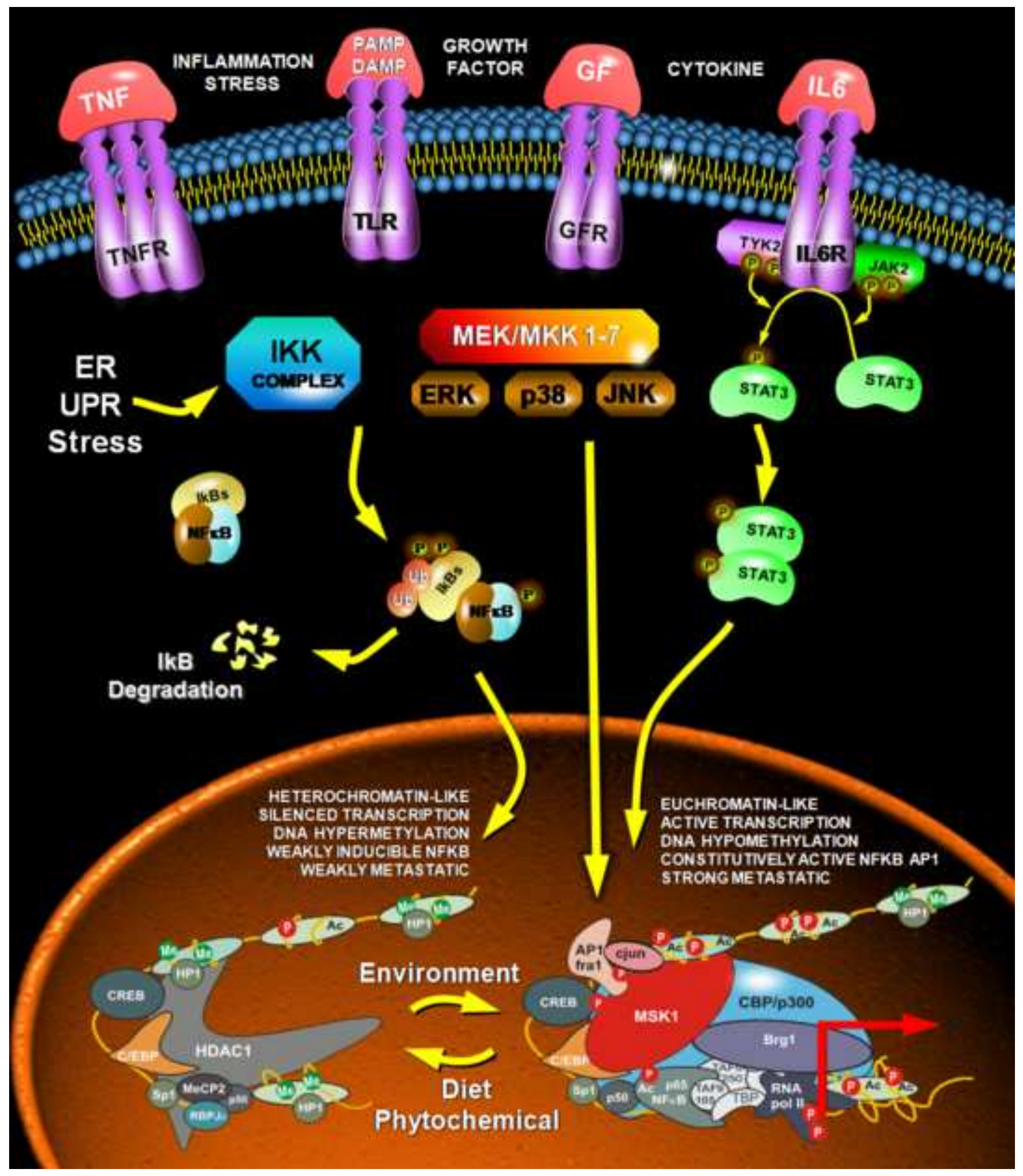

\section{TLR}

EUCHROMATIN-LIKE

ACTIVE TRANSCRIPTION

CONS TITU TIVELY ACTIVENFKB API TRONG METASTATIC
SILENCED TRANSCRIPTION

DNA HYPERMETYLATION WEAKLY METASTATIC$$
\text { . }
$$ 


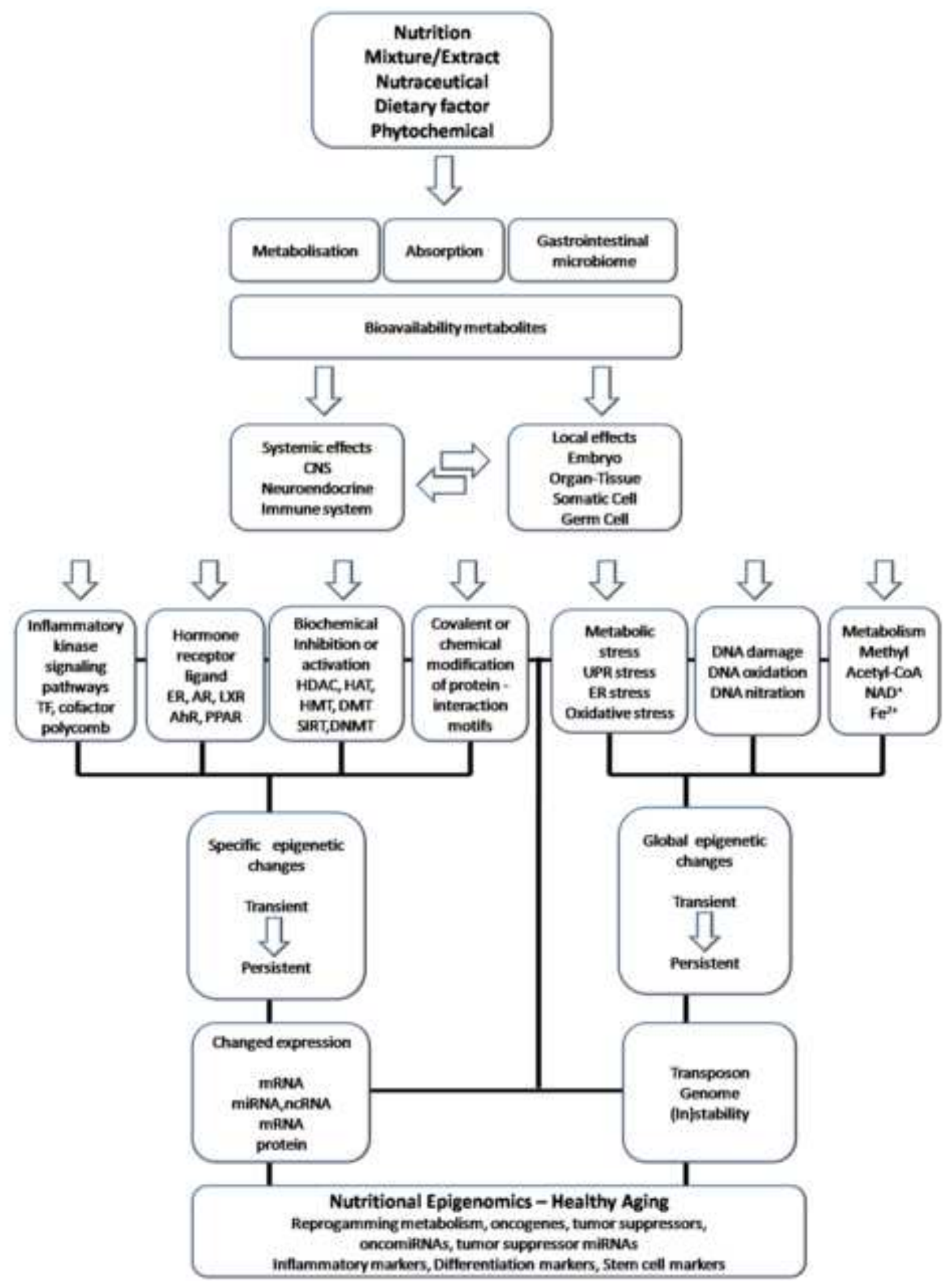

